Int. J. Dev. Biol. 53: 733-751 (2009)

doi: $10.1387 / \mathrm{ijdb} .072513 \mathrm{cj}$

\title{
The sudden appearance of diverse animal body plans during the Cambrian explosion
}

\author{
JUN-YUAN CHEN* \\ LPS of Nanjing Institute of Geology and Paleontology, Institute of Evo/Developmental Biology \\ and State Key Laboratory of Pharmaceutical Biotechnology, Nanjing University, Nanjing, China
}

\begin{abstract}
Beautifully preserved organisms from the Lower Cambrian Maotianshan Shale in central Yunnan, southern China, document the sudden appearance of diverse metazoan body plans at phylum or subphylum levels, which were either short-lived or have continued to the present day. These $\mathbf{5 3 0}$ million year old fossil representatives of living animal groups provide us with unique insight into the foundations of living animal groups at their evolutionary roots. Among these diverse animal groups, many are conservative, changing very little since the Early Cambrian. Others, especially Panarthropoda (superphylum), however, evolved rapidly, with origination of novel body plans representing different evolutionary stages one after another in a very short geological period of Early Cambrian time. These nested body plans portray a novel big picture of pararthropod evolution as a progression of step-wise changes both in the head and the appendages. The evolution of the pararthropods displays how the head/trunk boundary progressively shifted to the posterior, and how the simple annulated soft uniramous appendages progressively changed into stalked eyes in the first head appendages, into whip-like sensorial and grasping organs in the second appendage, and into jointed and biramous bipartite limbs in the post-antennal appendages. Haikouella is one of most remarkable fossils representing the origin body plan of Cristozoa, or "crest animals" (procraniates+craniates). The anatomy of Early Cambrian crest animals, including Haikouella and Yunnanozoon, contributes to novel understanding and discussion for the origins of the vertebrate brain, neural crest cells, branchial system and vertebrae.
\end{abstract}

KEY WORDS: body plan, head segmentation, evolution, appendage, brain, Cambrian explosion

The incredible 580 million year old Weng'an biota from Precambrian Doushantuo phosphate deposits reveals the presence of diverse metazoans including sponges (Li et la., 1998), cnidarians (Chen et al., 2000 and 2002; Xiao et al., 2000 and 2002a) and bilateral animals and related embryos (Chen et al., 2004a; Chen et al., 2006). Animal body organization patterns, especially in bilaterian animals, were diverse until the Early Cambrian (Chen 2004). However, early animals were mostly soft-bodied, and never left their mark on the fossil record except for the rare deposits of exceptional preservation, which preserve both soft tissues and the articulated complete skeletons.

The exceptionally preserved Cambrian fossils, especially the beautifully preserved fossils from the Lower Cambrian Maotianshan Shale deposits in areas (Chengjiang, and Haikou and Anning) adjacent to Kunming, China, document a sudden appearance of a diversity of metazoans that were not only remarkably diverse at the species level, consisting of over 100 species, but that show morphological disparity among them that provides the first manifest evidence for the appearance of the diversity of metaozoan body plans, which were either short-lived or have continued to the present day (Hou et al., 2004; Chen 2004).

Body plan (or body form) among animals is essentially the blueprint for the way the body of an organism is laid out (Raff, 1996; Hall, 1998). The blueprint is shared by a group of animals ranked at higher taxonomical levels (phylum, subphyla, class or order). It is characteristic of a unique anatomical body organization, is evolutinarily conserved, and deeply rooted.

The Lower Cambrian Maotianshan Shale lies at the heart of Cambrian explosive evolutionary event which gave rise to progenitors of living bilaterian animal groups including vertebrates, ascidians, priapulids, sipunculans, arrow worms, possible mol-

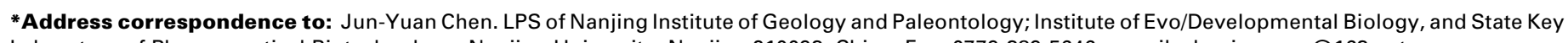
Laboratory of Pharmaceutical Biotechnology, Nanjing University, Nanjing,210093, China. Fax: 0779-389-5646. e-mail: chenjunyuan@163.net 
lusks, possible annelids, phoronida, and brachiopods (Chen, 2004; Hou etal., 2004). Among them, many have changed little since then (for instance, the ctenophores, priapulids, sipunculans, chaetognaths, tunicates and inarticulate brachiopods). On the contrary, limbbearing segmented animals known as panarthropods are not only diverse and abundant since the Early Cambrian, but also embrace diverse nested body plans that represent different evolutinary stages. Most of these different body plans appeared in the Early Cambrian. The emergence of novel body plans representing different evolutionary stages one after another near the root of the evolutionary history of the panarthropods are a remarkable and fairly unusual phenomenon, shedding light on the mysterious field of the evolutionary origin of various aspects of the arthropods, including head, limb, and brain evolution.

The origin of the neural crest cells is one of the most critical innovations in the evolutionary origin of the vertebrates. Holland and Chen recently coined the term Cristozoa, e.g. crest animals, referring to craniates and their immediate precursors (Holland and Chen 2001). Among the fossil representatives of the first crest animals, Haikouella lanceolata (Chen et al.,1999; Mallett and Chen, 2003; Chen, 2004, 2008 ) is the most remarkable one-because of its key evolutionary position at the very beginning of cristozoan history and by having extraordinary preservation of anatomical details. H. lanceolata, together with a slightly more advanced species Yunnanozoon lividum (Hou et al., 1991; Chen et al., 1995a; Chen 2004, 2008), constitutes a wonderful portrait for the original body plan of the crest animals, contributing novel understanding of the evolutionary origin of the vertebrate brain, head sensorial organs, branchial arches, backbones and feeding behavior. The Cristozoa hypothesis suggests the presence of a pre-craniate evolutionary history, which is marked by the innovation of a set of vertebrate characters, including: lateral eyes, possible nostrils, large differentiated brain (but lacking a telencephalon), protovertebrae and vertebrate type of branchial
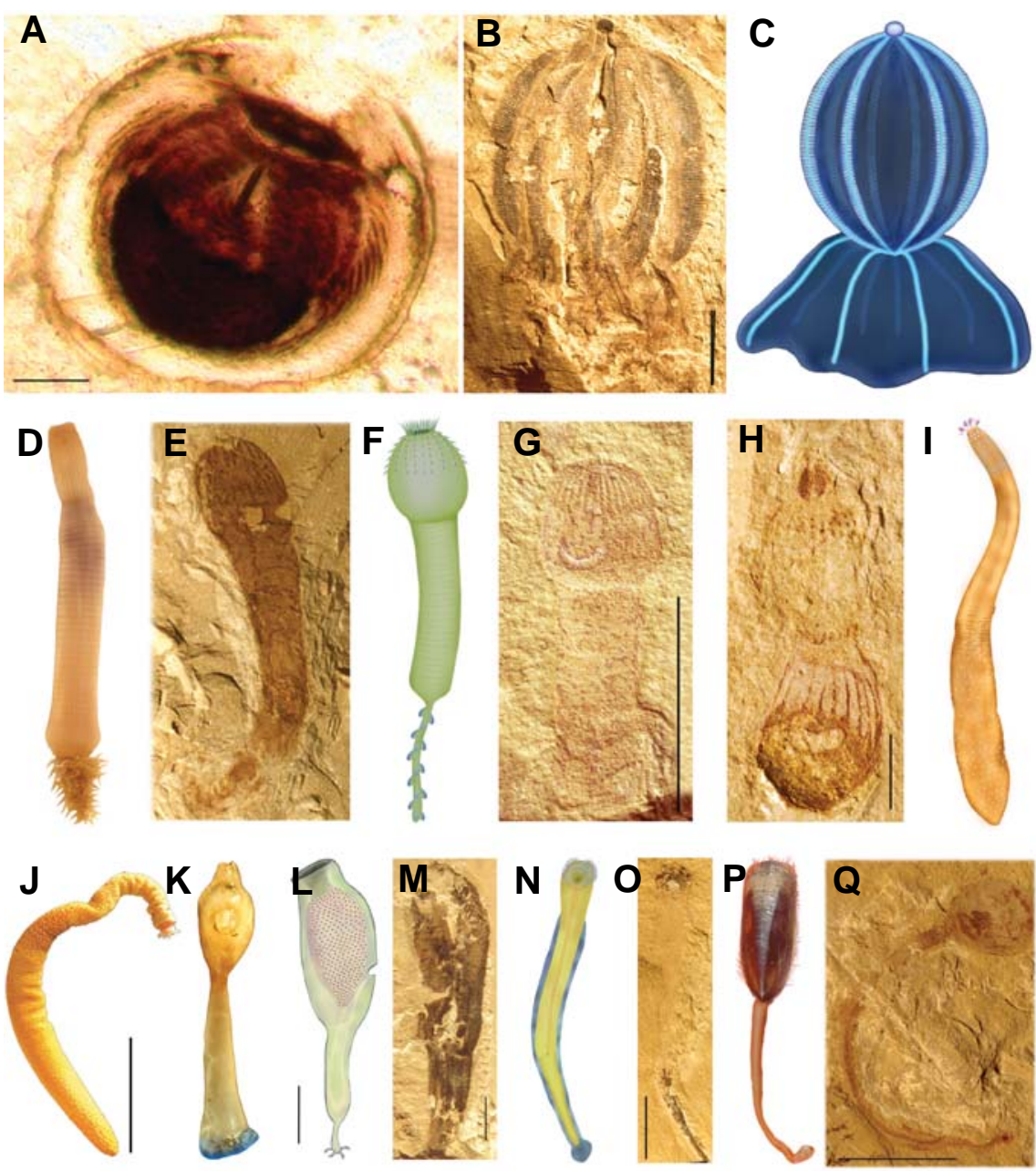

Fig. 1. Animal groups with conserved body plan. (A) Optical image of late developing ctenophore embryos from basal strata of Lower Cambrian, from Ningqiang, Shaanxi, China; (B-C) photograph (B) and restoration (C) of an adult ctenophore (Maotianoascus octonarius) from Lower Cambrian Maotianshan shale deposits, Chengjiang, Yunnan (southern China); D$H$, (D) Living (Priapulus caudatus) and (E-H) fossil priapulids including Xiaoheiqingella (E-G) and Palaopriapulites (H), from Lower Cambrian Maotianshan shale deposits, Chengjiang, Yunnan (southern China); (I-J), restoration of the Lower Cambrian sipunculan (Cambrosipunculus tentaculatus) from Chengjiang, Yunnan (southern China) (I) and a living sipunculan (Phascolosoma granulatum) from Biscay bay, Spain (J) (provided by Drs. J. Vannier and D.Y. Huang); (K-M) tunicates, a living tunicate (K) from Atlantic ocean (provided by Dr. B. Weber), and restoration (L) and photograph (M) of Lower Cambrian tunicate (Shankouclava anningense) from Anning, near Kunming (southern China); (N-O) restoration (N) and photograph (O) of Early Cambrian arrow worm Eognathacantha ercainella; $(P-Q)$ living (P) and Lower Cambrian Lingula (Q). Scale bars: A, 25 $\mu \mathrm{m} ; 1 \mathrm{~cm}$ in $B, J$, and $Q ; 0.5 \mathrm{~cm}$ in $E$ and $G$ and $O ; 0.25 \mathrm{~mm}$ in $H, L$ and $M$. system, and especially definite neural crest cells. The neural crest cells that predate the first appearance of the telencephaIon provide a possible answer to why neural crest cells are not formed in the developing telencephalon.

The affinities of numerous Cambrian animals remain controversial. The body plans of these animal groups, especially stalked sessile and pelagic medusiform lophophore-bearing animals and vetulicolian organisms yield clues to their possible affinities with extant animals.

The evolution of animal body plans provides us with interesting suggestions of how the genome architecture and develop- mental processes lead the course of evolution (Wang and Chen, 2004).

\section{Scarce animals with conservative body plans}

Maotianshan Shale deposits preserve fossil representatives of modern animal groups including ctenophores, priapulids, sipunculans, arrow worms, at phyla level, ascidians at subphylum level, and Lingula at order level. They are not only numerically scarce, but anatomical studies reveal that they are evolutionarily conservative. The evolutionary conservatism and rarity of these 
body organization patterns may imply the presence of underlying unknown evolutionary and developmental bottlenecks.

Ctenophores are a phylum of primitive triploblastic animals that have lived exclusively in marine settings since the Cambrian, representing one of the animal groups that are scarce and morphologically conservative except for some species that secondarily evolved to have 16 and 24 comb rows in the Middle Cambrian (Conway Morris and Collins, 1996), or rather bizarre body forms in some modern species (Brusca and Brusca, 1990). The ctenophore body plan as exemplified by both a 540 million years old, late developing embryo from basal strata of Lower Cambrian (Chen et al., 2007b) (Fig. 1A) and by 530 million years old adult forms from Maotianshan Shale deposits (Chen and Zhou, 1997; Chen, 2004) (Fig. 1 B,C), is almost identical to the body plan in extant ctenophores, and is characterized by having a spheroidal body that bears eight comb rows but lacks tentacles. Like some extant ctenophores, the mouth in adult ctenophores is surrounded by a broad skirt-like structure known as oral lobe.

Priapulids represent a minor phylum consisting only of 18 living species (Fig. 1D), exclusively of marine animals living in sand and soft mud (Ruppert et al., 2004). They first appeared in the Early Cambrian and were dominant animals in the endobenthic community both in the Lower Cambrian Maotianshan Shale (Chen, 2004; Huang, 2004a,b; Maas et al., 2007; Dornbos and Chen, 2008) and Middle Cambrian Burgess Shale fauna (Conway Morris, 1977), and are comprised of at least 11 species in Maotianshan Shale (Huang, 2006) and 3 species in Burgess Shale (Conway Morris, 1979). The body plan as exemplified by Cambrian adult priapulids is characterized by having an elongated body that is divided into a large trunk with an anterior introvert, and one or two caudal appendages (Fig. $1 \mathrm{E}, \mathrm{F}$ ). The body wall is covered with chitinous cuticle that bears of many types of scalids including setae, scales, and spines. The scalids are most abundant and stout on the introvert, where they are usually arranged in longitudinal rows. Interestingly, some Early Cambrian species (Xiaoheiqingella peculialis; Yunanpriapulus halteroformis; and Sicyophorus rara) (Fig. 1, G-H) retained a body form resembling priapulid larvae with a thick cuticular lorica. The lorica in modern species disappears during metamorphism. It is a case of paedomorphosis, retaining the larval characters into the adult. Priapulids are not only scarce in the post-Cambrian, but also evolutionarily conservative, having changed little since the Early Cambrian.

The sipunculans are a minor phylum, consisting of only of 250 living species and 25 genera. The body plan is characterized by having a non-segmental body that consists of an elongate, anterior introvert and a swollen posterior trunk. The anterior introvert is slender, in a length ranging one-half to several times the length of the trunk, ending with a mouth opening surrounded with tentacles. The digestive tract is J-shaped. They represent an scarce animal group with the body plan as exemplified by Archaeogolfingiaand Cambrosipunculusfrom Maotianshan Shale deposits (Huang et al., 2004) that shows little change since the Early Cambrian (Fig. 1, I-J).

Chaetognatha are a minor phylum of pelagic marine animals, consisting of only about 150 living species. Their body form is reminiscent of an arrow; hence they are usually called arrow worms. Their body plan is characterized by having a small slender body with a strikingly perfect bilateral symmetry and divided into a distinct head, finned cylindrical trunk and a dorso-ventrally- flattened, finned post-anal tail. The head is ovoid, bearing a depression that leads to a ventral mouth. The vestibule is flanked laterally with prey-seizing grasping spines. Eognathacantha(Chen and Huang 2002) and Protosagitta (Chen et al., 2002, 2008) are the fossil representatives of the first arrow worms from the Lower Cambrian Maotianshan Shale. The body form of this group as exemplified by the Lower Cambrian species (Fig. 1, N-O) has changed little since the Early Cambrian.

Tunicates of the subphylum Urochordata represent a basal branch of the known chordates. Shankouclava shankouense (Chen et al., 2003) from the Maotianshan Shale represents a solitary sessile adult tunicate, with a body consisting of a barrelshaped anterior thoracic region containingna large pharyngeal basket, an elongated, triangular abdominal region containing a $U$ shaped digestive tract, and post-abdominal attaching stolons (Fig. 1, L-M). An oral siphon opens subventrally, containing oral tentacles at its base. An endostyle band extends along the midventral part of the pharynx, and a sac-like atrium surrounds the pharyngeal basket. The striking resemblance of Shankouclava (Fig. 1, L-M) with extant tunicates (Fig. 1, K), suggests that tunicates have changed little since the Early Cambrian.

Living Lingula, of the phosphate-shelled inarticulate brachiopoda, lives in brackish to intertidal sandy substrata and has persisted since the Early Cambrian (Jin et al., 1993) with few changes (Chen, 2004). The body plan of Lingulais characterized by having gently convex valves, and an elongated pedicle extending from the valves (Fig. 1, P-Q). The animal lives in a vertical position within a burrow. The two valves of Lingula close by the use of adductor muscles.

\section{Panarthropod body plan evolution}

Panarthropods are likely a monophyletic taxon, sharing a body pattern which includes the following several important characteristics: a segmented body, paired appendages, and a chitinous cuticle that they molt during ecdysis (Ruppert et al., 2004). The presence of pyramid-yolk embryos (Chen et al., 2004c) and late developing embryos with segmented germ band (Chen, 2004; Steiner et al., 2004) at very basal part of the Lower Cambrian Meishucun phosphate deposits suggest that they were deeply rooted at very beginning of Cambrian about 542 million years ago or even before. The exceptionally well-preserved fossil fauna from the 530 million years old Maotianshan Shale deposits provides a fossil record of remarkably diverse arthropods that embrace a number of body organizations representing of different evolutionary stages, including worm-like stem lineage panarthropods referred to as Tardiopolypoda (Chen and Zhou, 1997); stem lineage arthropods (proarthropods) (Chen, 2004; Waloszeck et al., 2005);'stem lineage euarthropods; and the possible ancestral form of the two major extant euarthropod groups, e.g, Chelicerata (Chen et al., 2004b) and Mandibulata (Chen et al., 2001). These nested body plans of different evolutionary stages suggest the presence of step-wise and condensed evolutionary events, which led in the line of evolution from wormlike ancestor to euarthropods within a short geological time of about 12 million years in the Early Cambrian.

\section{Body plans of the stem groups of the Panarthropoda}

Among the Panarthropoda, worm-like organisms with unjointed 
limbs from the Lower Cambrian referred to as Tardipolypoda (Chen and Zhou, 1997) are least complex, and are likely the fossil representatives of the first panarthropods. They are diverse, composed of Luolishania (Hou and Chen,1989), Microdictyon sinicum (Chen et al., 1989; Ramsköld and Chen, 1998), Cardiodictyon catenulum (Hou et al., 1991), Onychodictyon ferox (Hou et al., 1991), Paucipoda inermis (Chen et al., 1995d) and Hallucigenia fortis (Hou and Bergstrüm, 1995; Ramsköld and Chen, 1998) in the Maotianshan Shale fauna. These taxa share several important characteristics, including: segmental soft body with paired appendages; an undifferentiated head, which is either segmented, or of non-segmental origin; and mouth and anus situated at each of the terminal ends (Ramsköld and Chen, 1998; Ramsköld, 1992). The segmented head consists of one or two pairs of head appendages.

The anatomical analysis of these tardipolypods reveals that they are separated by morphological gaps into several different groups, which testify to the presence of an initial and very rapid period of evolution at the base of the Panarthropoda. Their head contains the following three different types of organization, e.g.: non-segmental head (Microdictyon sinicum, Paucipoda inermis and Luolishania longicuris); segmented head with a pair of head appendages (Onychodictyon ferox); segmented head with two pairs of head appendages (Cardiodictyon catenulum and Hallucigenia fortis)(Fig. 2). The species within the non-segmented head group display great morphological variation and their trunk segments varied from only 6 to up to 16 . Their body wall was either entirely soft and flexible as in $P$. inermis, or had pairs of composite-eye-like sclerites as in the trunk of $M$. sinicum and 2-3 small hardened sclerites on the dorsal side of each trunk segment as in L. longicuris. The head in L. longicuris was interpreted to bear a pair of "head appendages" (Chen, 2004), which are here reinter-

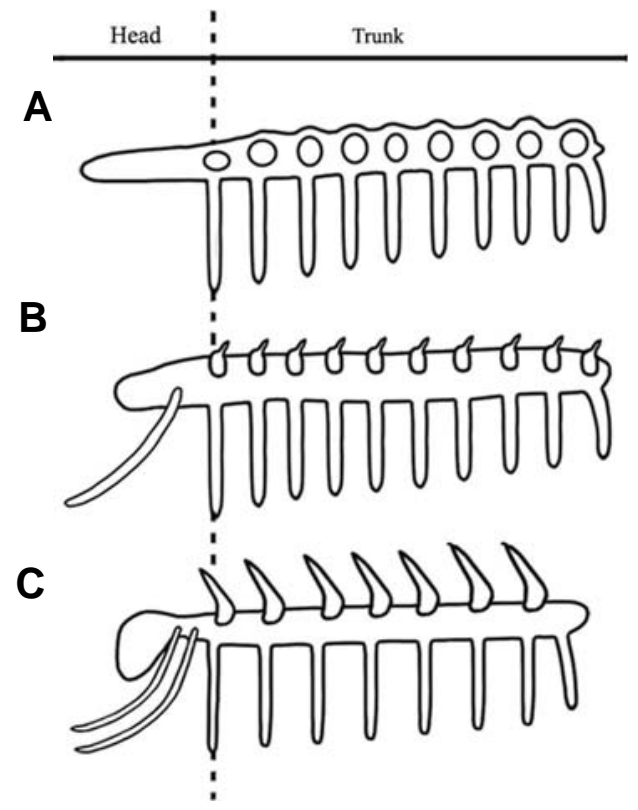

Fig. 2. The body organizations in stem groups of Panarthropoda. (A) Non-segmented head, exemplified by Microdictyon sinicum; (B) onesegmental head with a pair of head appendages, exemplified by Onychodictyon ferox; (C) two-segmental head with two pairs of head appendages, exemplified by Hallucidegia fortis.

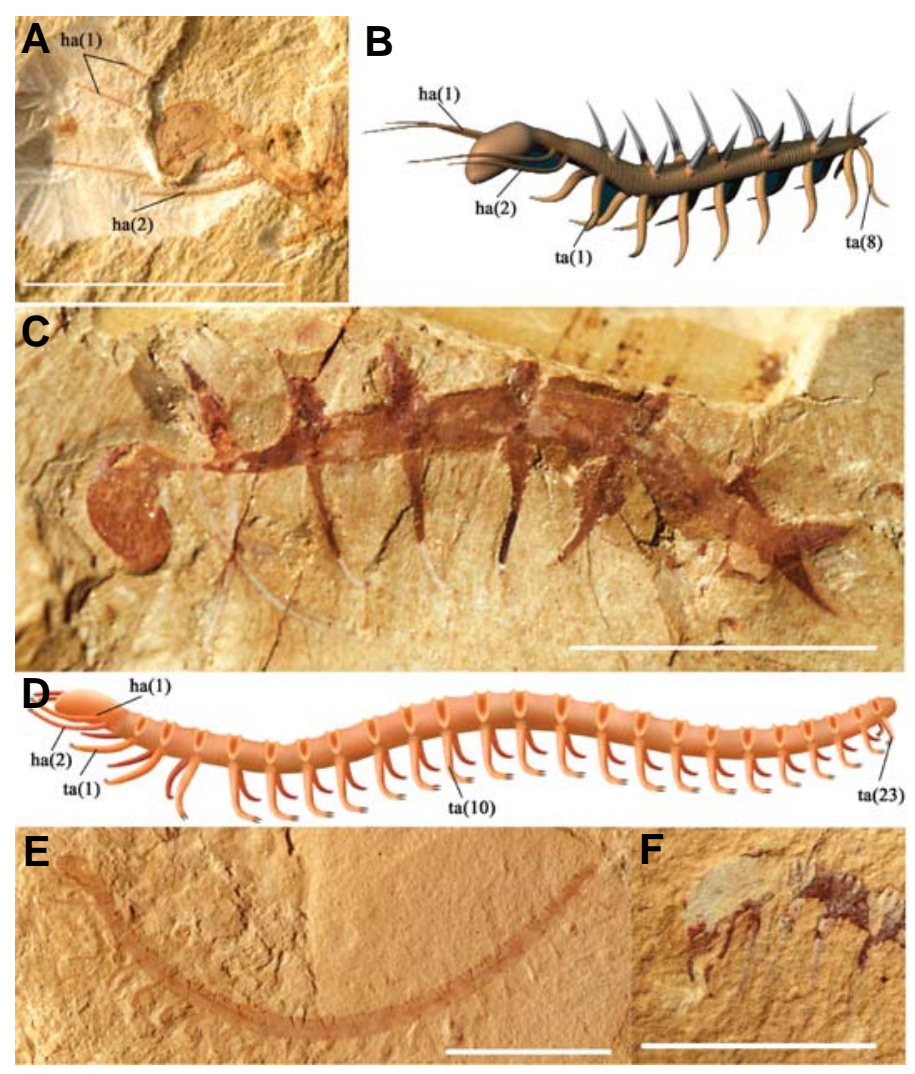

Fig. 3. The two-segmental head worm-like organisms from Lower Cambrian Maotianshan Shale deposits. (A-C) Photographs $(A, C)$ and restoration (B) of Hallucigenia fortis. (D-F) Restoration (D) and photographs $(E, F)$ of Cardiodictyon catenulum. Abbreviations: ha, head appendage; ta, trunk appendage. Scale bars are $1 \mathrm{~cm}$ in $(A, C, E) ; 0.5 \mathrm{~cm}$ in (F).

preted as the first trunk appendage because of the presence of hardened sclerites. Liu and her collaborators (Liu et al., 2004) recently erected a new lobopodian Miraluolishania haikouensis that represents an intermediate between lobopodians and arthropods. This animal preserves paired small hardened sclerites dorsally on each pair of appendages and the "possible dorsal sessile eyes" seemly represent the anterior-most paired sclerites. M. haikouensis has shared features with Luolishania. These features include; body form, number of appendages, and dorsally-situated small hardened sclerites. I reinterpret $M$. haikouensis as a possible synonym or sister species of $L$. longicuris.

The one-segmented head body plan is represented only by a single species Onychodictyon ferox. Its trunk bears 10 pairs of hard sclerites on each side. The head bears a pair of appendages in a close similarity with the trunk appendages but more laterally situated. Among the three types of tardipolypod body plans, the two-segmented head type yields remarkable interest for the understanding of the evolutionary origin of Arthropoda. The resemblance of this two-segmented head with that in the first arthropods known as proarthropods argues for the origin of arthropods, which may have evolved from an ancestor with a close resemblance to the two segmented head tardipolypod clade. The body plan of the two segmented head tardipolypod clade as exemplified by Cardiodictyon catenulum (Fig. 3, D-F) and Hallucigenia fortis (Fig. 1, A-C) had a two segmented head 
that was in an elongated ovary form with mouth on its ventroanterial terminal and a pair of appendages in each of head segments. The trunk bore pairs of harden sclerites on lateral ( $C$. catenulum) or on dorso-lateral sides $(H$. fortis) of trunk segments.

\section{Body plan of the Arthropoda}

Among the fossil assemblage of arthropods from Maotianshan Shale deposits, a group of arthropods were defined recently as stem group of arthropods, called proarthropods (Chen, 2004), which include Fuxianghuia protensa (Hou, 1987), Shankouia zhenghei(Waloszek etal., 2005 and 2007) and Chengjiangocaris longiformis (Hou \& Bergström, 1991). Among these 3 species, $F$. protensa is the first one being described at a basal position among Euarthropoda (Chen et al. 1995b), having a head made of two tergite-bearing segments (Chen et al. 1995b; Hou and Berström, 1997)(Fig. 4, A,B; Fig. 5). In their interpretation, the second tergite was interpreted to bear two pairs of appendages. The "second pair of limbs" is however denied by evidence of their internal location between dorsal and ventral cuticles (Waloszek et al., 2005). The authors reinterpret them as a pair
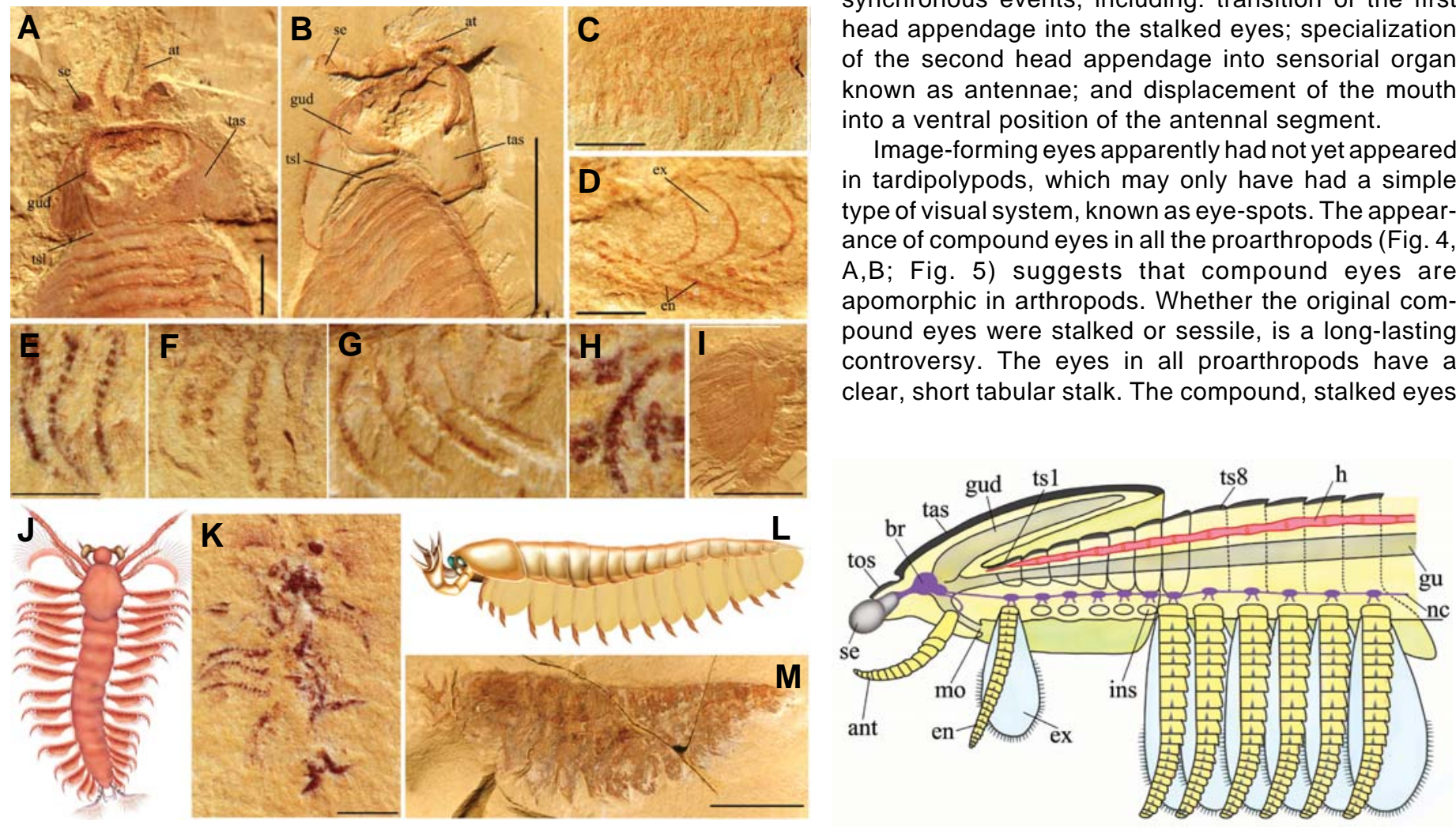

Fig. 4 (Left). Lower Cambrian arthropods. (A,B) Dorsal view of the anterior-displacement of the 2-segmental head and the anterior trunk portion of Fuxianghuia, showing the following features: stalked eyes, antennae, a large posterior-extended head shield and gut diverticula. (C,D) Biramous trunk appendages of Shankouia, showing lobopodian-like endopods and simple flap-like exopods. (E-H) Tubular-shaped, multi-segmented endopods among stem groups of the Euarthropoda. (I) Bipartite endopod with expanded and serrated basipod of a stem group of the Euarthropoda. (J,K) Restoration and photograph of the first Mandibulata, Ercaia. (K-L) Restoration and photograph of Haikoucaris, showing a pair of cheliceae-like structures consisting of 2 segmented peduncle and 3-finged claw. Abbreviation: at, anetennae; en, endopod; ex, exopod; gud, gut diverticula; se, stalked eye; tas, tergite of antennal segment; ts, trunk segment. Scale bars: $2 \mathrm{~mm}$ in $(A, G) ; 1 \mathrm{~cm}$ in $(B, C, I, M) ; 0.2 \mathrm{~mm}$ in $(D, E, H) ; 1 \mathrm{~mm}$ in $(F, K)$.

Fig. 5 (Right). Schematic restoration of the tentative groundplan of the Arthropoda. Abbreviation: ant, antennae; br, brain; en, endopod; ex, exopod; gu, gut; gud, gut diverticulum; h, heart; ins, inserter; mo, mouth; nc, neural cord; se, stalked eyes; tas, terigite of antennal segments; tos, tergite of the ocular segment; ts, tergite of the trunk segment. This figure is adapted from Fig. 4 in Waloszek et al., (2005). 
arguably characterize the original body plan for the arthropod eyes. The tabular, possibly segmented eyestalk represents tabular extensions of the body wall in homology with tubular limbs, which argues for segmental origin for the anterior-most head part in arthropods and evolved from the anterior-most, limbbearing head segment in worm-like ancestor resembling the Hallucigenia-Cadiodyctyon clade.

The flagilliform antennae have long been accepted as the original arthropodian version of the uniramous antennae (Fig. 4A). The long and multi-segmented flagelliform antennae widely appear among trilobites and extant arthropods with a mainly sensorial function. This flagelliform hypothesis however is refuted by the present study of the proarthropods, whose antennae are short and stout, consisting of a limited number of segments, about 15 (Fig. 4A). These short, limb-shaped antennae occurring both in all proarthropods and in some stem lineage euarthropods (Canadaspis, Primicaris and bradoriids, and Ercaia) represent the groundplan of the arthropod antennae (cf. Maas et al., 2004).

The mouth in the groundplan of the Panarthropoda, as exemplified by tardipolypods, is situated at the terminal end of the body and in arthropods the mouth is located on ventral side of the antennal segment. The displacement of the mouth to a new position represents one of the major evolutionary changes in the origin of arthropods. The looped anterior digestive track in arthropods argues for this mouth displacement as the result of the back curving of the first head segment. C. catenulum (Fig. 3, DF) and $H$. fortis (Fig. 3, A-C) have an expanded and ventrallycurving head and an anterior-ventrally situated mouth, representing an intermediate stage during mouth displacement.

The transformation of uniramous trunk limbs into biramous trunk limbs was one of the important changes during the origin of arthropods and it was marked by innovation of the flap-like exopods (Fig. 4, C,D; Fig.5). The exopods represent the extended pouch of body wall adjacent to the base of limb. They morphologically resemble insect wings, suggesting that the developmental process of the exopods is similar to that for wing development. It suggests that the coordinating genetic cassette for the insect wing-developing is very ancient, used by the first arthropods for exopod development. It was recruited later by insects for wing morphogenesis.

The groundplan of the arthropod trunk-limbs, as exemplified by Shankouia zhengheiand possibly Chengjiangocaris longiformis, is biramous, with the least differentiation among the different segments except for Fuxianghuia protensa, which had a trunk differentiated into a limb-bearing thorax and a limb-less abdomen. This limb-less abdomen is a secondarily derived feature, likely a result of the repressed expression of the Distalless gene. The groundplan of the arthropod endopods is a simple tubular form, consisting of multi-segments. It is not much different from the groundplan of the panarthropod limb except for the existence of pivot joints between two adjacent segments in the endopods of the arthropod groundplan. The presence of pivot joints suggests the presence of intrinsic muscles in the first arthropod endopod.

\section{Groundplan of the Euarthropoda}

Walossek has established Euarthropoda as representing a monophyletic group that includes all the extant arthropods and some extinct arthropod lineages, such as trilobites, naraoiids, and numerous others (Walossek 1999; Maas \& Walossek 2001). The monophyletic status of the Euarthropoda as proposed by the authors, is based on them having a head consisting of the ocular, antennal and three biramous limb-bearing segments: the postantennal limbs composed of a rigid and antero-posteriorly compressed basipod and seven or fewer jointed endopods (Fig. 4I). Therefore it means that the transition of Proarthropods to Euarthropoda was marked by two separate events, e.g., the evolutionary origin of multiple, segmented syncephalons; and the formation of euarthropod limbs. The fossil evidence however shows that these two events were not synchronic and the origin of the syncephalon event predates formation of euarthropod limbs.

Whereas the head in extant arthropods is composed of either 6 segments in Madibulata or 7 segments in Chelicerata, the head in Lower Cambrian arthropods, except for proarthropods, mostly contains 5 segments. The head in the euarthropod groundplan was five-segmented, composed of ocular, antennal, and three post-oral segments. The anterior two segments, referred to as the procephalon, constitute the anterior head part that is in a homology virtually to proarthropod head. The ocular segment in most species had a pair of stalk eyes but stalk-less sessile eyes were also very common among the stem groups of the euarthrpods. These sessile eyes were either fixed dorsally on the head shield as seen in trilobites, or ventrally in trilobitomorphs and Misszouia. These sessile compound eyes are secondarily derived; presumably the expression of the Distaless gene (organizer center for tabular structure) in these species had been selectively repressed by otd/ems in the ocular segment.

During the transformation of proarthropods to euarthropods, the antennae in the antennal segment either remain unchanged, or specified into the flagelliform sensorial organ or raptorial limblike feeding organ. The origination of raptorial limb-like antennae was the first evolutionary event that led the evolutionary line forward to the Chelicerata.

The groundplan of the euarthropodan post-oral head, as exemplified by stem-lineage euarthropods from the Maotianshan Shale, is characterized by a three segmental mode, and each of the segments carried a pair of the least differentiated biramous appendages in homology with trunk appendages. Unlike to the other stem-lineage euarthropods, the post-oral head in Ercaia minuscule was comprised of 4-segments, whose first pair was in a specified form corresponding to the second pair antennae of the Crustacea (Chen etal. 2001). Presumably Ercaia minusculeis the fossil representative of the ancestral form of the Mandibulata, which was deeply rooted among the proarthropods or among the proarthropod-euarthropod transition.

The post-antennal limb design of the euarthropod groundplan has been defined as a bipartite mode, with an expanded proximal portion (called basipod) and a distal portion (consisting of 7 or less segments). This bipartite post-antennal limb is associated with feeding and locomotion function respectively (Walossek and M ller, 1990; Walossek, 1993). It has been interpreted to be monophyletic and the key novel event in the origin of Euarthropoda. This monophyletic hypothesis is however challenged by fossil evidence from the Lower Cambrian Maotianshan Shale. Instead of the predicted bipartiate limb, the tabular and multi-segmented post-oral limb widely occurred among distally separated stemgroups of early euarthropods, including: the first Mandibulata (Ercaia minuscule) (Fig. 4, E,K) and the stem-groups of Chelicerata 
(Leachoilia, Fortiforceps and Tanglangia) and other extinct euarthropods (Saperion, Canadaspis, Isoxus, bradoriids, and Primicaris). The limb in some species is in a tubular shape, having a slight differentiation along its main axis, and consisting of about 14 segments (Primicaris lavaformis, Ercaia minuscule; Canadaspis laevigata) whereas it in other species consists of fewer segments and displays a bipartite form with an expanded and segmented proximal portion (Cindarella eucalla, Saperion glumaceum and Isoxus) (Ramsk^ld et al., 1997; Chen, 2004). This bipartite, multisegmented limb-design presumably represents an intermediate stage from least differentiated tubular form to bipartate mode. The limb design in Saperioncomprises 9 segments and the 3 proximal segments are expanded with serrated inner edge (Ramsk^ld et al., 1997). I speculate that these 3 serrated segments are the precursor of the expanded basipod and the basipod may have evolved from these expanded proximal limb-segments through their fusion.

\section{Possible groundplans of Mandibulata}

The extant arthropods including Crustacea, Hexapoda, Myriapoda and Chenlicerata can be grouped into two deeplyrooted clades, the Mandibulata and the Chelicerata. Extant Mandibulata is composed of the Hexapoda, Myriopoda and Crustacea. The head segmentation and related appendages in the Hexapoda and Myriaopoda are homologous with those in Crustacea except for the first post-oral segment, which is known as intercalary segment in stead of $2^{\text {nd }}$ antennae. The intercalary segment has long been regarded as an appendage-less structure until recently when the labrum was reinterpreted as fused paired appendages of intercalary segment (Finkelstein and Perrimon, 1991; Popadic et al. 1998; Boyan et al., 2002) and the head was reinterpreted in the 6-segmental mode (Zacharias et al., 1993; Minelli, 2001). The six segments in the insect head are arranged from anterior: ocular, antennal, intercalary, mandibular, maxillary and labial segment. The insect head segmentation and related structures show a striking homology with those in Crustacea, suggesting that insects (possibly including Myriopoda also) likely originated among the Crustacea or from a crustacean-like ancestor. The transition from $2^{\text {nd }}$ antennae into a feeding organ known as labrum through anteriorly-displacement and the fusion of the paired $2^{\text {nd }}$ antennae was one of major changes in the origin of the insect.

Ercaia minuscule from the Maotianshan Shale has a 6-segmented head and the first pair of the modified post-oral appendages corresponds to the $2^{\text {nd }}$ antennae in extant Mandibulata. It was first described as an ancestral form of Crustacea (Chen et al. 2001) and here is interpreted as the fossil representative of the first Mandibulata.

The head in Mandibulata groundplan as exemplified by $E$. minuscule is composed of 6 segments, which are arranged from anterior: ocular, the $1^{\text {st }}$ antennal, the $2^{\text {nd }}$ antennal, and 3 least differentiated appendages (Chen et al., 2001). This early Mandibulata was small, 2-4 mm long, and had an ocular segment identical basically to that of proarthropods. Like the ocular segment in proarthropods, it was small, and had an oval tergite jointed posteriorly with head shield, and a pair of stalked compound eyes attaching ventro-laterally to this segment. The antennae resemble those in proarthropods in general morphology but they bear setae, suggesting more advanced than the setae-lacking antennae in proarthropods. The $2^{\text {nd }}$ antennae are a newly derived character, composed of a relatively small 4-5-segmented endopod and a large crescent-shaped exopod with prominent setae on its margin. Posterior to the A2, there are likely three biramous head appendages, which resemble trunk appendages. The endopods in post- A2 appendages are in a tubular shape, consisting of 14 segments. The primitive nature of the homologous, post-A2 head appendages in E. minusculesuggest that Mandibulata was deeply rooted at very basal position of the arthropod evolutionary history. Recent discovery of an epipodite-bearing eucrustacean Yicaris from Yonshan, Yunnan (not far from the fossil site of E. minuscule) within stratum about coetaneous with the Lower Cambrian Maotianshan Shell (Zhang et al., 2007). These finding indicates that the first appearance of Eucrustacea were much earlier than we thought.

\section{Groundplan of the Chelicarata}

Chelicerates are widely accepted as an unquestioned, basic monophyletic group of the Arthropoda. They share a distinct and conservative body plan, with features such as the prosomal opisthosomal subdivision; and a cheliceral segment with a pair of morphologically unique chelicerae. Chelicera is named for the presence of a pair of modified head uniramous appendages called chelicerae. The chelicerae consist only of 3 articles, the proximal peduncle and distal two, which form of chela. The chelicerae were long been regarded as the modified second antennae and on basis of molecular developmental and neurobiological study now reinterpreted as the modified first antennae. The groundplan in chelicerate head consists of a two-segmental anterior head and 5-segmental posterior head (Dunlop 1999; Chen et al., 2004b). In its anterior head the ocular segment bears dorsal sessile compound eyes and antennal segment bear a pair of anteriorly-pointing raptorial uniramous appendages, the chelicera. The posterior head as exemplified by Silurian Offacolus kingibear 5 pairs of biramous appendages (Sutton et al. 2002).

The large modified antennae known as the "great appendages" have long been recorded from the Early to Middle Cambrian. These "great appendages" that comprise proximal peduncle and distal claw are similar to chelicerae in general morphology. Despite the similarity, no one had ever realized the possible evolutionary relationship of these peculiar Cambrian "great appendage" arthropods with Chelicerata until the fossil finding of Haikoucaris ercaiensisin 2004 (Chen etal., 2004b) (Fig. 4, L-M). This animal recorded from the Lower Cambrian Maotianshan Shale has a pair of chelicerae-like structures, which fill the morphological gap between the Cambrian "great appendage" and the chelicerae of the crown-lineage Chelicerata. This chelicerae-like structure consists of the 2-segmental peduncle and 3 -fingered claw. It resembles chelicerae but had one more segment both in its peduncle and claw, and similar to the "great appendage" but one segment less in claw of most Cambrian "great appendage" creatures. Because of the striking homology with chelicerae, I here call these "great appendage" as prochelicerae, which are interpreted as a precursor of the chelicerae.

The head ground plan in Chelicerata, as exemplified by prochelicerata, is a five-segmented model. The five segments are arranged from anterior as follows: ocular segment, procheliceral segment, and 3 post-antennal segments. Each of the 3 post- 


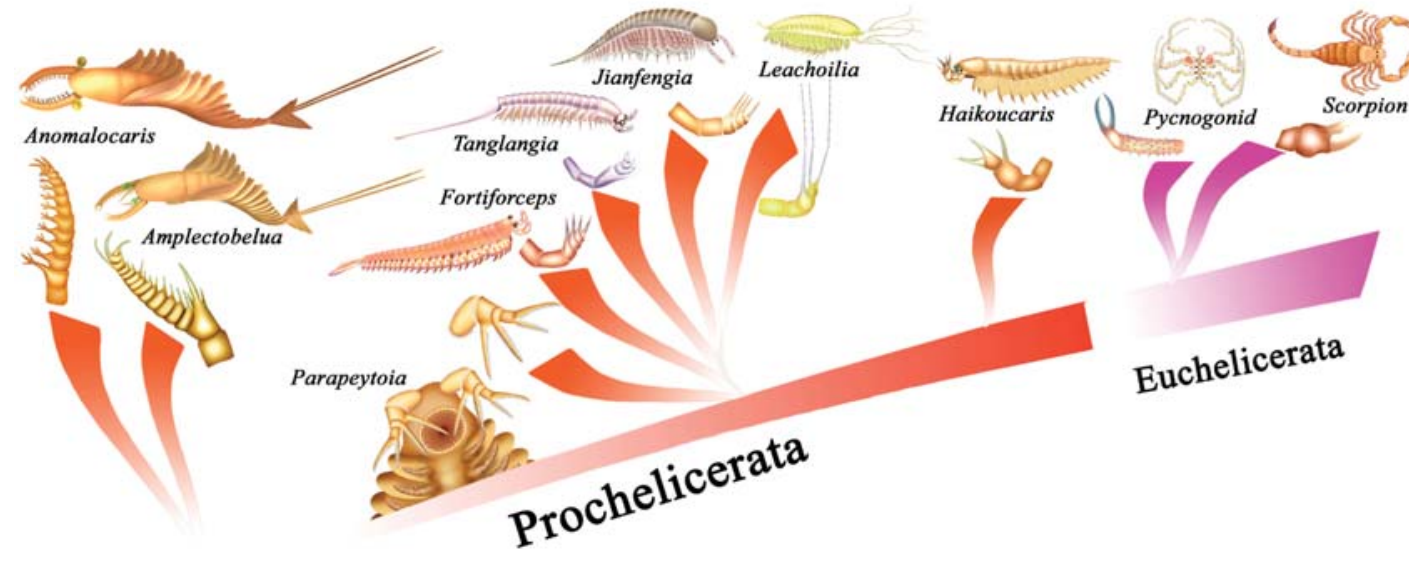

Fig. 6. Summary model of the major change in grasping head organ in antennal segment of Chelicerata. preted as a hemichordate (Shu et al., 1996 and 2003b). The hemichordate hypothesis was heavily based on the misinterpretation of several key anatomical characters of this animal, and was refuted by Chen and Li (1997). Yunnazozoon not only has a mandibular arch but is also preserved with a pair of large lateral eyes in a complete specimen (Fig. 7, A,B), suggesting a more advanced phylogenic position than that of Haikouella (Chen 2004, 2008). The presence of $W$ - antennal segments has a pair of biramous appendages identical to those in the trunk. Their endopod is mostly in simple, multisegmented with least differentiation along the main axis (Fortiforceps foliosa, Leachoilia illecebrosa, and Tanglangia longicaudata), but Haikoucaris ercaiensis has only 7 segments, likely grouping into two function portions. The primitive nature of the limb design in most of Prochelicerata suggests that Chelicerata was deeply rooted among the stem-lineage arthropods. The transformation of the short, stout antennae into bipartite prochelicerae was the first key event that led to the line of the Chelicerata evolution. The transformation of Prochelicerata to Euchelicerata in head is marked by the two likely synchronous events: e.g., the reduction of the procheliceral segments and the recruitment of 2 more segments from trunk (Fig. 6).

\section{Cristozoan groundplan}

Neural crest cells contribute to the development of peripheral neural system, endocrine glands, pigment cells, most of the bones and cartilage of the skull, the bones and cartilage of the jaw and pharyngeal arches, and the teeth. Hall (2000) suggests vertebrates are quadroblastic organisms, with the neural crest constituting a fourth germ layer. The neural crest apparently was a watershed for dividing of the vertebrates from their invertebrate ancestor and Holland and Chen (2001) therefore coined a term Cristozoa (the crest animals) for representing craniates and their immediate precursors, although Wada (2001) suspected the neural crest cells as a novel vertebrate cell population.

Among the most significant fossil discoveries from Lower Cambrian Maotianshan shale are the fish-like early crest animals including Haikouealla (Chen et al., 1999; Chen and Li, 2000; Holland and Chen, 2001; Mallatt and Chen, 2003), Yunnanozoon (Hou et al., 1991; Chen et al., 1995a), Haikoichthus and Myllokunmingia (Shu et al., 1999b and 2003a; Hou et al., 2002), which represent different evolutionary stages in the line toward craniates. Among them, Haikouealla is one of the most primitive crest animals, lying at basal position of the Cristozoa evolution (Fig. 7, C-J; Fig. 8). Yunnanozoon(Fig. 7, A,B) is a close relative with Haikouealla. Because of incompleteness in the earlier discovered specimens, the phylogenic affinities of Yunnanozoon have been a subject of controversy and this animal was first described as a chordate (Chen et al., 1995a) and later reinter- shaped myosepta and fin rays suggests that Haikoichthus and Myllokunmingia are possible true craniates (Javier, 1999). They however lacked a mineralized skull and the reliable evidence for supporting the presence of telecephalon and otic capsules, casting the shadow on these animals as true craniates. Alternatively, Haikoichthusand Myllokunmingiamay represent advanced forms of the pre-craniate crest animals.

Presence of the visceral skeleton, branchial denticles and the evidence of muscular ventilation suggest that Yunnanozoonand Haikouella had definitive neural crest cells and were definitive crest animals (Holland and Chen, 2001; Mallatt and Chen, 2003). The presence of the neural crest allowed the crest animals to become one of the most successful animal groups. These two early crest animals display a number of characters typical of vertebrates, but they lack some vertebrate characters, such as a skull, ear, fin rays, and definitive telencephalic forebrain. These vertebrate features must have evolved at later stages in the evolutionary line leading to craniates (Mallatt and Chen, 2003), arguing for the existence of pre-craniate evolutionary history among the crest animals. The crest animals therefore embrace stem- and crown- groups.

Among the stem group of the crest animals, Haikouella is a most remarkable one. This animal has preserved with extraordinary details of key anatomical characters including brain, eyes, oral tentacles, muscle fabrics (Fig. 8) and other organs and at a very basal position in the evolution history of the crest animals, provides a unique key for novel understanding of the groundplan of the crest animals.

The groundplan of the crest animals as exemplified by Haikouella and Yunnanozoon has an elongated, lancelet-like body only a few centimeters long which was bilaterally symmetrical. A distinct head bears a pair of eyes on lateral sides, nostrils on front, and a ventral buccal cavity at its hind end. It also has large pared lips and a distinct lower lip (Fig. 8). Similar characters also exist both in agnathans and in sharks (Mallatt, 1996), representing apomorphic characters of the Cristozoa (Fig. 8). The oral cavity has a pre-pharynx position, with a skeletal ring for supporting oral tentacles. This tentacle-supporting ring is a sharing feature with cephalochordates, also present in larval lamprey, possibly representing plesiomorphic character of the Cristozoa.

The groundplan of the Cristozoa pharynx system as exemplified by Haikouella is characterized by having only 6 post-man- 
Fig. 7. Fossil representatives of the early crest animals from Lower Cambrian. (A,B) Part and counterpart of a completely-preserved Yunnanozoon specimen from Chengjiang, Yunnan (souterhn China), showing: a pair of big eyes, pharynx with 7 pair of branchial arches; 13 pairs of gonads; gut and notochord. (C) A laterally compacted brain in anterior part of Haikouella. (D) Mouth, upper lip, lower lip, gill pouch, brain, spinal cord in a laterally compacted head of Haikouella. (E,F) Dorso-ventrally compacted, anterior portion of Haikouella, showing brain with a pair of olfactory lobe and optic nerves. (G) A laterally compacted specimen of Haikouella, showing eyes, oral cavity with tentacles and right and left branches of mandibular artery. (H) A head of Haikouella, with preservation of brain, a pair of eyes, and nostrils. (I) Pharynx of Haikouella, preserved with mandibular artery, branchial arches, dorsal and ventral aorta and endostyle. (J) Laterally compacted Haikouella showing: cartilage protovertebrae, connecting tissues and its dorsal margin, dorsal margin of notochord. Abbreviation; ba, branchial arch; br, brain; ct, connecting tissue; da, dorsal arteria; dc, diencephalic brain; en, endostyle; ey, eye; gn, gonad; gp, gill pouch; gt, gut; hb, hindbrain; II, lower lip; ma, mandibular artery; ma(r+l), right and left limb of mandibular artery; mo, mouth; ms, myoseptum; ns, nostrils; nt, notochord; ol, olfactory lobe; on, ocular nerve; ph, pharynx; pv, protovertebrae; sc, spiral cord; t, tentacle; ul, upper lip; va, ventral arteria. Scale bars, $2 \mathrm{~mm}$ in $A-B, D-F$, and $H-J ; 1 \mathrm{~cm}$ in $C, G$.

dibular arches and lacking a mandibular arch (Fig. 7l; Fig. 8). The mandibular re-
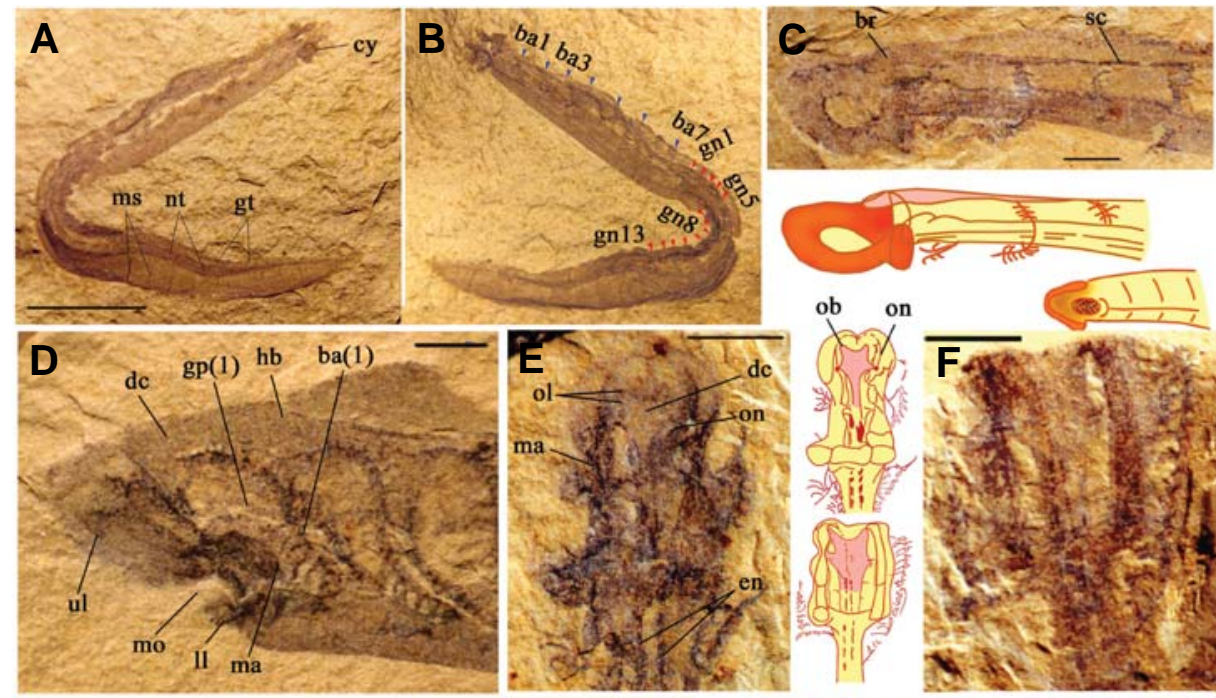

ob on
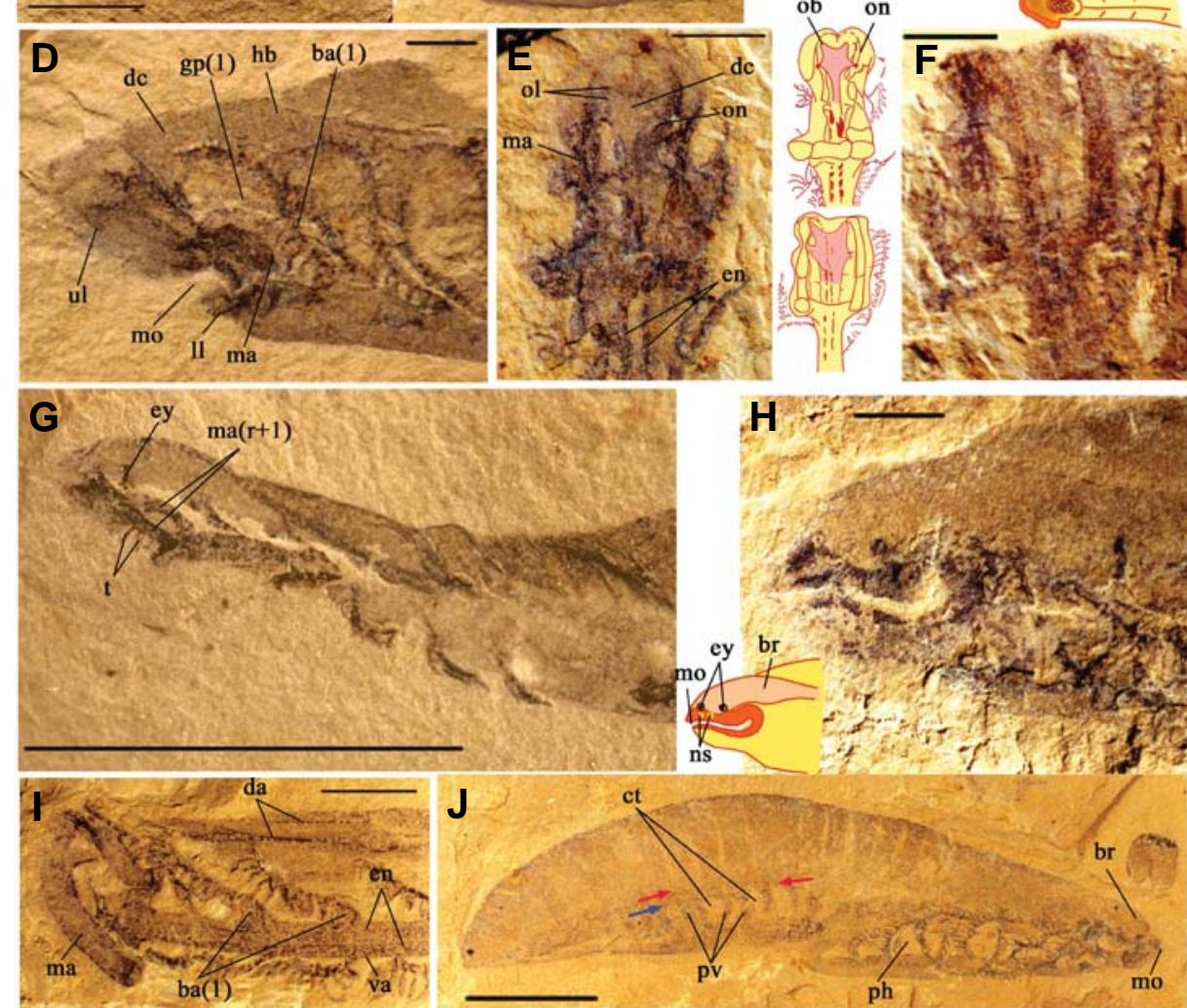

gion is marked by the mandibular artery without branchial bar associated with this artery. Yunnanozoon had 7 branchial arches and the first pair corresponds to the mandibular bar. It suggests that the origination of the mandibular arch was not synchronous with that of the post-mandibular arches, but occurred in a later time among the pre-craniate history. These branchial arches are separated by wider branchial slits, and relatively thicker and jointed but least differentiated along their main axis. The widely spaced, thick skeletal branchial bars indicate that the muscular ventilation mechanism had evolved at very beginning of the cristozoan evolutionary history. The pharynx as evidenced by Haikouella and Yunnanozoon is protected by a pair of water chambers known as atria. Atria are a plesiomorphic character and are also present in proto-chordates including ascidians and cephalochordates but disappear in craniates. The atria are a plesiomorphic character of the crest animals and might function for protecting the gills from muddy and sandy substratum during swimming or hov-

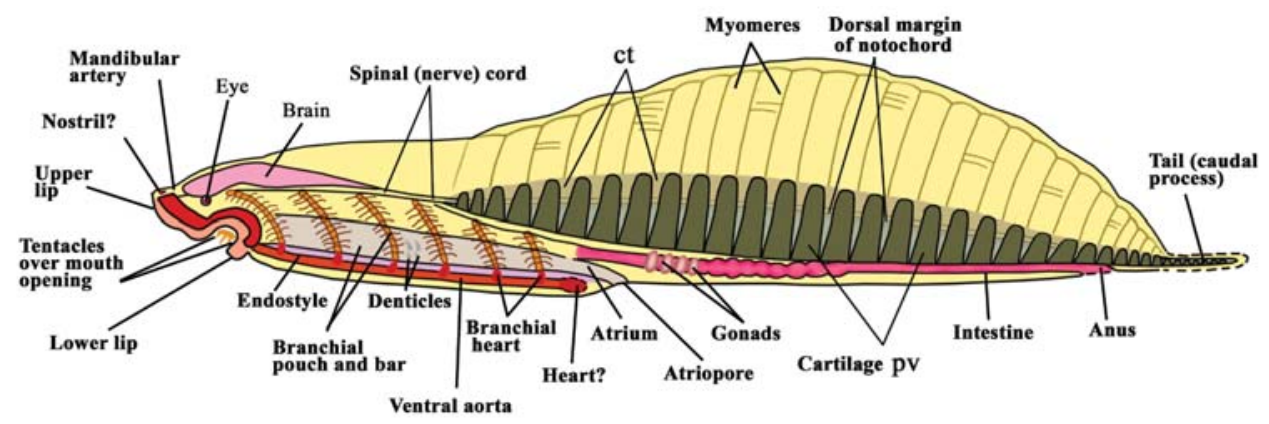

Fig. 8. Anatomy of the Early Cambrian crest animal, Haikouella. ering close to the muddy sea bottom (Holland and Chen, 2001).

The brain in the Cristozoa groundplan as exemplified by Haikouellais relatively large and expanded at the pre-mandibular location (Fig. 7, C-F; Fig. 8). This pre-mandibular part of the brain interruptedly contains mainly the diencephalon and middle brain at its hind end. The hindbrain is elongated and narrows posteriorly by its end at the third (vagal) branchial bar (Fig.7, C). Dorso-ventrally compacted specimens confirm the absence of large cerebral hemispheric structures related to telencephalon 
brain, except for a pair of small bulges that are interpreted as olfactory lobes (Fig. 7, E-F).

Vertebrates get their name from their axial skeleton known as the vertebral column and it is a vertebrate-only character, but is not best developed until the mammalian evolutionary stage. The notochord is the axial hydrostatic skeleton, which is a chordateonly character. The notochord-only axial structure appears only in larval stage of urochordates but welldeveloped throughout the life in cephalochordates. Notochords exist in vertebrates throughout their life, but it tends to degenerate, and the mineralized vertebral column instead of notochord plays the role of axial skeleton. That origin and timing of vertebral column evolution remains a great puzzle.

The axial skeleton in the Cristazoa groundplan as exemplified by Haikouella and Yunnanozoon is characterized by having a large distinct notochord and cartilage protovertebrae (Fig. 7J; Fig. 8 ). The notochord presents throughout the life cycle, resembling that in cephalochordates that have an elongated form, narrowing anteriorly over the pharynx and posteriorly in the caudal process. It was enclosed in a thick sheath that consists of circular and oblique fibers, the same as in extant chordates (Fig. 7J; Fig. 8). This sheath is continuous with a layer of a connecting tissue; within this connecting tissue there develop irregular cartilaginous thickenings comparable to protovertebrae of the extant lamprey (Young, 1981; Chen and Li, 2000; Holland and Chen, 2001). This cartilage protovertebrae is the precursor of the vertebral column and represents an apomorphic character of the crest animals.

Muscle segments (myomeres) and the myosepta (or myocommata) between the segments are present in both extant cephalochordates and craniates. In these taxa, the myosepta have a complex $\mathrm{V}$ or $\mathrm{W}$ shape. In Haikouella and Yunnanozoon, there are about 2 dozen myomeres, which are separated by myosepta (Fig. 1., J; Fig. 8). Different from V or W shape, these myosepta however are simply straight. Because of their unusual simplicity and dorsal location, they were reinterpreted as a large, segmented fin (Shu etal., 1996) and as cuticular rings (Conway Morris, 2000). Preservation of muscle fibers in some Haikouella and wrinkled overlying skin on the myomeres in some Yunnanozoon confirm that these segmental structures are truly myomeres (Chen and Li, 1997; Mallatt and Chen, 2003). The simply myosecta may represent a primitive character of the crest animals. The resemblance in the complex shape of the myosepta between cephalochordates and advanced crest animals presumably evolved through parallel evolution. Young larvae of lancelets and tunicates with the same simple straight, segmental muscles swim well (Holland and Chen, 2001).

Simple cone-shaped denticles exist on the pharyngeal floor in Yunnanozoon and Haikouella. It suggests that the teeth are deeply rooted, representing an apomorphic character of the Cristozoa, and they have emerged before the onset of mineralized dermal skeletons. The early teeth as exemplified by Haikouella and Yunnanozoon were simply cone-shaped, situated on the pharyngeal floor.

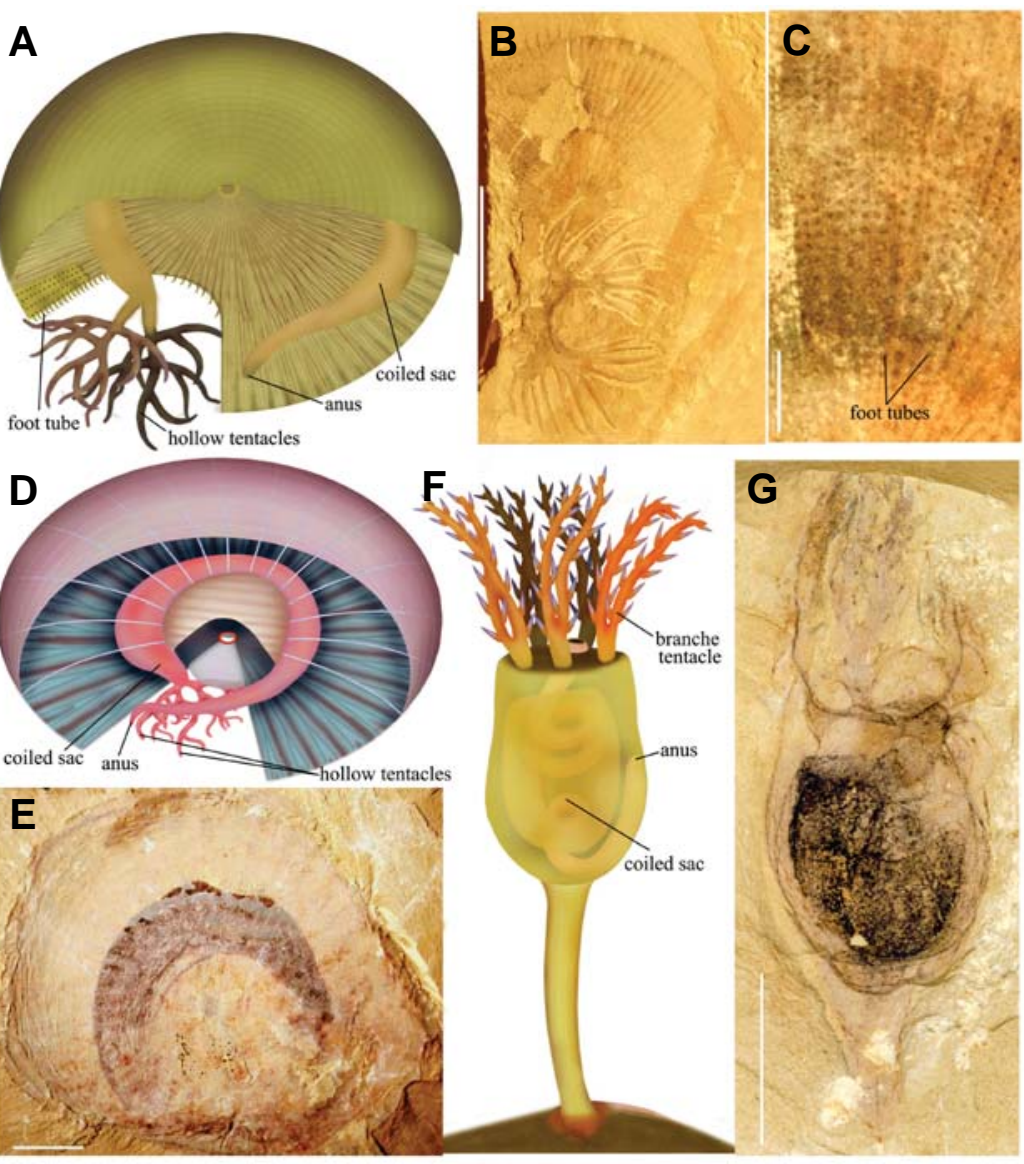

Fig. 9. Early Cambrian lophophore-bearing animals. (A-E) The pelagic medusiform ophophore-bearing animals, Rotadiscus $(A-C)$ and Eldonia $(D-E)$. (F,G) Solitary essile lophophore-bearing animals, Phlogetes (=Chenungkongella). Scale bars all

\section{Body plans of the lophophore-bearing animal groups}

The diversity of Cambrian metazoan body plans includes some whose relationships to modern phyla have been controversial (Gould, 1989). Two major groups of Early Cambrian enigmatic animals both had a crown of hollow ciliated tentacles (also called a lophophore) encircling their mouth. Their anus lies outside the tentacle crown but nearby. One of the enigmatic groups is represented by Phlogites (Chenungkongella), which was a solitary sessile suspension feeder (Fig. 9, F,G). Phlogites was softbodied, with a goblet body, which consisted of a proximal stalk, a calyx and branched circumoral arms. The gut was coiled, Ushaped, with the anus on the side of body. This animal had been interpreted either as a tunicate (Shu et al. 2001a) or as an endoproct (Luo et al. 1999). The body plan, based examination of more completely preserved specimens, shows this animal was likely not a tunicate, or an endoproct, but likely a lophophorate animal (Chen et al., 2003).

The medusiform animals Eldonia and Rotadiscus represent the other animal group which were dominant among the Cambrian pelagic community (Fig. 9, A-E) (Walcott, 1911b; Sun and Hou, 1987; Chen et al., 1995c; Zhao and Zhu, 1994; Zhu et al., 2002). The body plan of Eldonia and Rotadiscus is characterized by having a low bell-shaped body, with a convex upper surface 
and a concave lower surface. The upper surface was soft-bodied, supported by fine tabular structures in Eldonia or a weakly mineralized hard skeleton in Rotadiscus. The internal anatomy is however asymmetric and complex, having a sub-horizontally clockwise (viewing from above) coiled sac. The alimentary canal situates dorsally in the coiled sac, ending with mouth and anus ventrally, both off the centre on one side of the disc and close to each other. A crown of hollow branched tentacles encircles the mouth. A hydraulic sac lies ventrally in the alimentary canal and it is divided into numerous segmental parts. These hydraulic compartments extend radially. Each of these radially-extended sacs bears a canal, which connected with a ring canal centrally and bifurcated in its peripheral part. The lower surface is softbodied, bearing radial rows of elongated structures, which correspond in distribution to the radial canals (Fig. 9, C). These structures are $0.2 \mathrm{~mm}$ wide and $0.35 \mathrm{~mm}$ long but the innermost one is much larger and comparable to foot tubes in echinoderms.

The phylogenic affinity of the medusiform organisms, especially Eldonia, has evoked much controversy since 1911 when it was originally described as a holothurian (Walcott, 1911), or considered as an echinoderm (Clark, 1912; Croneis and McCormack, 1932). Contrary to the echinoderm hypothesis, it has proposed been as a Cnidaria, but being placed into different groups in Cniadarians, as a siphonophore (Madsen, 1956), a coelenterate medusa (Lemche, 1960), a scyphozoan (Sun and Hou, 1987), and as a sedentary (Dzik et al., 1997) or pelagic lophophorate (Chen et al., 1995). Conway Morris and Robison (1988) and Chen and Erdtmann (1989) interpreted it as a problematic. These medusiform organisms had a well-developed water vascular system that resembles that in echinoderms, suggesting that they were likely a basal deuterostome, closely related with echinoderms. Walcott original interpretation is correct.

\section{Body plan of the vetulicolians: are they basal deuterostomes?}

Among Cambrian organisms, vetulicolians (Shu et al., 2001b; Chen and Zhou, 1997) are one of the big Cambrian puzzles whose affinities have been controversial, being considered as an extinct arthropodan Class called Vetululida (Chen and Zhou, 1997) or as a deuterostome group, either basal (Shu et el., 2001b) or more derived, likely close to the tunicates (Gee, 2001; Lacalli, 2002; Chen et al., 2003; Aldridge et al., 2007). The recent issue of one of the vetulicolians, Xidazoon (junior synonym of Pomatrum; Luo et al., 1997) as a vertebrate (Shu et al., 1999a) is one of the most disparate views with arthropodan or arthropod-affinity hypothesis (Chen \& Zhou, 1997; Bergstr^m \& Hou, 2003; Chen, 2004; Briggs et al.,2005; Caron, 2006).

Vetulicolians were large Cambrian animals, sharing a body plan that has a body with super- ficial resemblance to tadpole larvae, composed of a simple coneshaped head (Fig. 10A), a larger expanded segmented thorax and a dorso-ventrally-flattened abdomen (Fig. 10, B-C). Their mouth and anus lay at either terminal end of the body.

The head is only well represented in a few specimens, in resemblance to the head of the tardipolypods. The head in both animal groups is non-segmental and cone-shaped, lacking eyes and other structures, with a small mouth situated at the terminal end.

The expanded thorax represents the anterior half of the trunk, being laterally compressed (Vetulicola, Didazoon and Heteromorphus), or rounded (Pomtrum"=Xidazoon' and Banffia). It is segmented, divided into various sub-equal segments, mostly six, but sometimes fewer, possibly five in Heteromorphus and uncertain in Banffia (possibly numerous). Each of the thoracic segments in most species had a pair of distinct gas exchange organ "gills" (Fig. 10, G-H), which were contained in the branchial
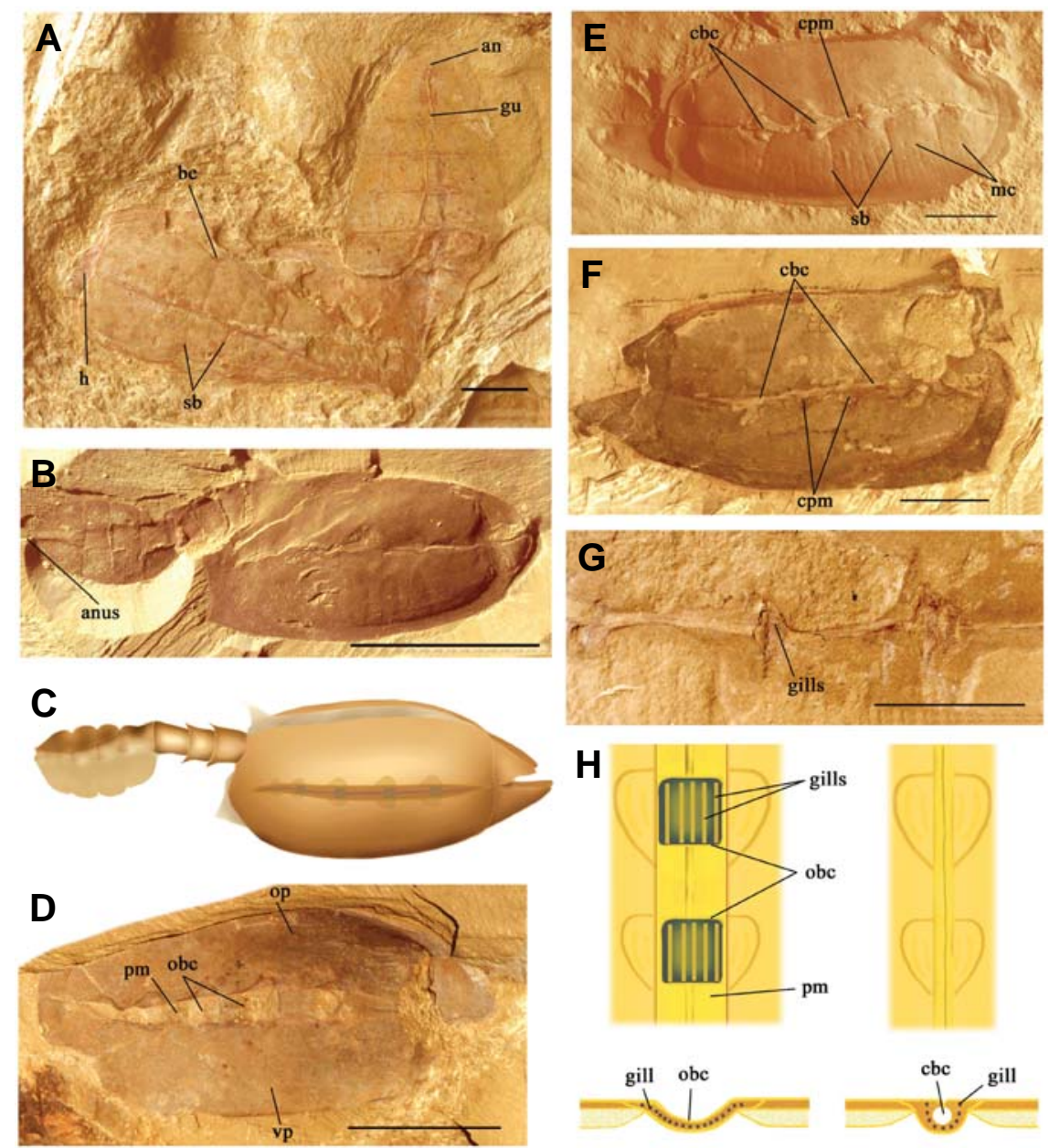

Fig. 10. Early Cambrian arthropod-like animals. Vetulicolia: (A) a complete, dorsallycompacted specimen of Pomatrum (=Xidazoon), preserved with a short-conic head, segmented thorax and abdomen. (B-H) Specimens (B, D-G), restoration (D) and schematically drawing of the branchial chambers in Vetulicola, showing: close ( $E$, right column of $H$ ) and open state ( $C, D$, left column of $H$ ) of the pleural area and related branchial chambers, and gills (G). Abbreviation: bc, brachial chamber; cbc, closed branchial chambers; cpm, closed pleural member; $h$, head; mc, microscopic canal; obc, open branchial chambers; pm, pleural member; sb, segmental boundary. Scale bars all are $1 \mathrm{~cm}$. 
chambers formed by subsidence of the body wall (Fig. 10, E-H). Similar structures are also present in many modern decapod crustaceans. The gills are contained in the branchial chamber that provides protection for the fragile gill filaments.

The exoskeleton design in the thoracic region is similar to arthropods because it is differentiated transversely into the following four parts, e.g., a dorsal and ventral hard plate, two lateral flexible pleural membranes between ventral and dorsal plates (Fig. 10, C,H). The dorsal and ventral plates were usually finned in the median plane. The exoskeleton of the dorsal and ventral plates is relatively thick, consisting of a thin, dark outermost layer and a thick, pitted inner layer. The outer layer presumably corresponds to the epicuticle of arthropods, bearing a smooth outer surface, whereas the inner layer corresponds to procuticle of extant arthropods, that bears microscopic canals (Brusca and Brusca 1990). Between the dorsal and ventral plates are lateral pleural membranes, which are the flexible part of the thorax, extending longitudinally through the entire length of the thorax. The pleural areas bear five or four pairs of pear-shaped brachial chambers concealed within the pleural membrane. These chambers had been interpreted as the homology of the gill pouches in chordates (Shu et al., 2001b). In contrast, the body wall is continuously extended, representing subsidence of the body wall that conflicts with the "gill-pouches" hypothesis.

The abdomen was compacted dorso-ventrally in an oar-like form, lacking appendages. It is segmented and each segment is boxed by a dorsal plate, two narrow lateral pleural joints and a ventral plate (Brusca and Brusca, 1990). The segmented sclerites are jointed with an arthropodial membrane.

Deuterostome affinity of the vetulicolians is refuted by evidence of the segmented, jointed exoskeleton that is an arthropodonly character. The putative deuterostome gill slits are actually a subsidence of the body wall and the similar structure know as branchial chambers are also present in a number of modern decapod crustaceans. Whereas the segmented, jointed exoskeleton shows affinity with arthropods, the non-segmented head with the mouth at the terminal end in vetulicolians denies their arthropod identity. Their head however resembles that of some tardipolypods (Microdictyonand Paucipodia) with non-segmented heads. One may speculate that vetulicolians had evolved among tardipolypods but from a species different than that which led to the line of arthropod evolution.

\section{Discussion}

\section{Evolution of head segmentation in Panarthropoda}

The head in arthropods is composed of serial segments but the serial homology and segmental identity in the extant arthropod head have been obscured by fusion, modification and replacement in some taxa, especially insects. Because of this, the head segmentation in arthropods has been a long-lasting controversy regarding these questions: how many segments and which ones are nested in the head; how many head segments are in the ancestral groups of the arthropods; and is the anterior head segmental or non-segmental origin? The comparative studies of the fossil representatives in different evolutionary stages from the Lower Cambrian Maotianshan Shale contribute novel understanding to the answers of these questions.

The Cambrian limb-bearing worm-like animals known as tardipolypods represent stem-lineage panarthropods. This animal group has a simple tagmosis of the body into an anterior head and a posterior trunk. Its head is scarcely distinguishable from the trunk and its appendages are similar to those in the trunk but are more dorsally situated. The tardipolypods contain three different types of head, e.g. non-segmented head, one segmental head and two segmental head. Among them, the two segmental head has a special interest for sharing an identical number of head segments with that in the stem-lineage arthropods known as proarthropods. The groundplan of the arthropodal head as represented by proarthropods was short, comprised of two segments, which corresponding respectively to the ocular and antennal segment of the anterior head region of euarthropod syncephalon (Fig. 5; Fig. 11B). This 2-segmental primitive head is known as procephalon. The ocular segment bears a pair of stalk eyes and the antennal one has a pair of short antennae.

The morphological gap between the two-segmented head in

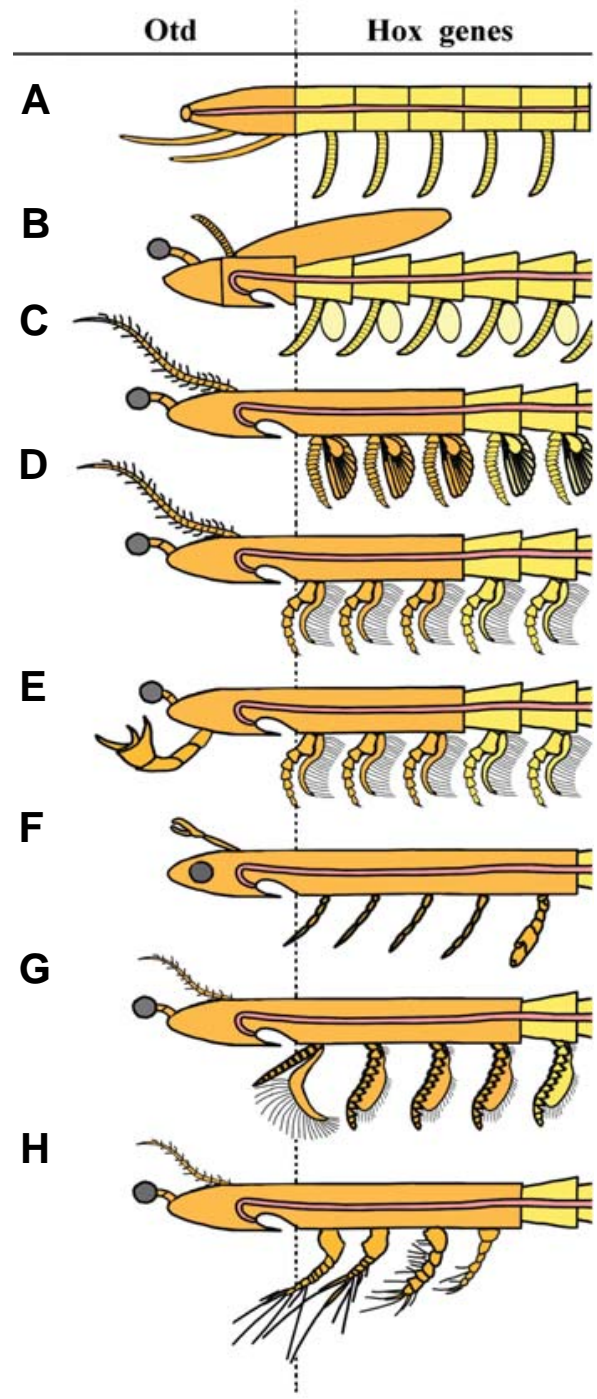

Fig. 11. Head groundplans of: Pararthropoda (A); Proarthropoda (B); stem-lineage Euarthropoda (C-D); Chenlicarata (E); Euchelicerata (F); Mandibulata (G); and Eucrustacea (H). Brown color representing head; yellow, trunk. 
tardipolypods and arthropods is very great and the evolution of the tardipolypod head to the arthropod head occurred rapidly and remains poorly understood.

The evolution of arthropod head segmentation is marked by the recruitment of new segments from the trunk to form the new post-oral head region. The Maotianshan Shale yields diverse stem groups of the euarthropods, whose head had more segments, usually 5 (Fig. 11, C-E). The 5-segments are the principal characteristic of the groundplan in the arthropod head, whose anterior 2 segments are virtually identical to the head in proarthropods. The posterior 3 ones are a novel structure, which were presumably recruited from the anterior trunk. The question of why the first head expansion of exactly 3 segments from trunk remains a puzzle.

Stem lineages of Euarthropods are diverse in the Maotianshan Shale deposits. Unlike proarthropods, the head in the stemlineage euarthropods is larger, composed of 5 segments. The anterior 2 segments are virtually identical to the head in proarthropods. The posterior 3 segments are additional structures, which were presumably recruited from the anterior trunk through the loss of related joints between the anterior trunk tergites. Each of the segments carries a pair of appendages identical to that in the trunk. Why the first head expansion that had recruited 3 but not in other different segments from trunk remains mysterious. The head in crown lineage arthropods however contains more than 5 segments, 6 in crown groups of Mandibulata and 7 in the crown groups of Chelicerata (Fig. 11). This suggests that the head segmentation in crown lineages of Euarthropoda has been achieved with two separated expansion events.

The presence of a stem-group crustacean (Ercaia) with a 6segmental head from the Lower Cambrian Maotianshan Shale suggests that the second event of head expansion in the Mandibulata was deeply rooted among the proarthropod/ euarthropod transition in the Early Cambrian (Chen et al., 2001), and predated the second event of head expansion in the Euchelicerates. A 7-segmental mode characterizes the groundplan in the euchelicerate head and it suggests that the second expansion event occurred in the Silurian when the first known 7segmental chelicerate head is reported from fossil the record (Sutton et al., 2002).

\section{Is the anterior-most part of the head a true segment or does it represent the non-segmental acron?}

Because the head in insects has been highly modified and some of its structures have been displaced, the head segmentation and the identity of the head structures have long been an issue of controversy. The labrum (or upper lip), a plate-like process anterior of the mouth field, is the most unexpected structure. It led some authors to speculate that the anterior-most head part is of non-segmental origin. They coined the term "acron" for representing this non-segmental part. The acron includes the labrum only according to some authors (Snodgrass, 1935; Rempel, 1975; Scholtz, 2001) but it has been interpreted to represent a fused anterior head part including the labrum, eye and protocerebrum (Brusca and Brusca, 1990). Based on the above interpretation, the pre-oral head part is composed either of a nonsegmental part and two segments, or of a non-segmental part and a segment. The appendicular origin of the labrum however has been well supported both by embryological (Eastham, 1930; Butt,

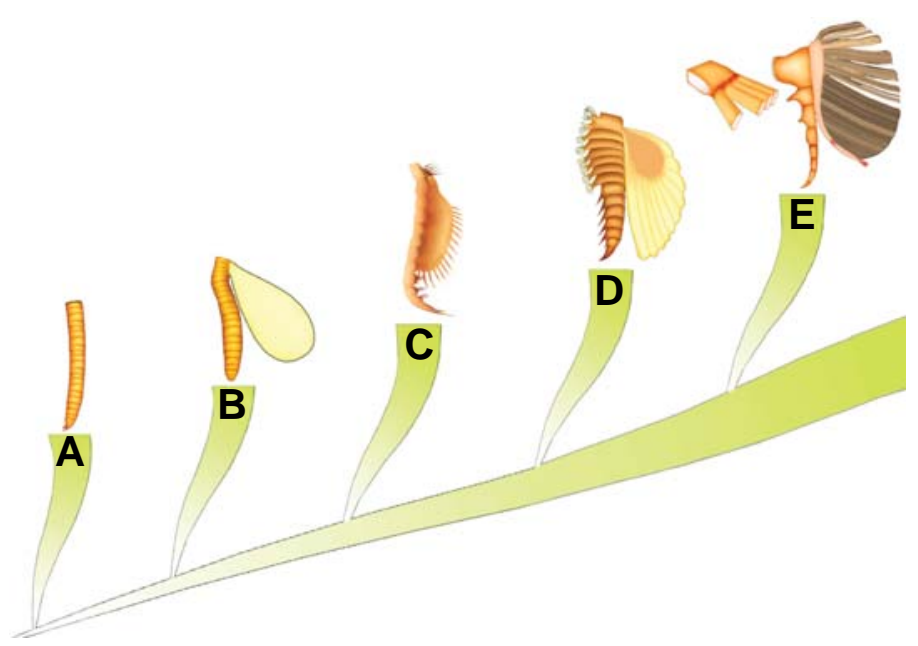

Fig. 12. Post-antennal limb designs of: (A) stem-groups of Panarthropoda, in uniramous, multi-annulated tubular form; (B) Proarthropoda, in biramous, with a flap-like exopod and a simple tubular, multi-segmented endopod; (C-D) stem groups of Euarthropoda, in biramous structure, with endopods, which are either in a simple, multisegmented tubular form (C), or differentiated into a distal and an expanded multi-segmented proximal domain (D); (E) advaced form of stem groups in Euarthropoda, in a distinct bipartite structure consisting a distal limb and an expanded large basipod with serrated inner edge (D).

1960; Rempel, 1975) and molecular developmental studies (Schimidt and Technan, 1992). The questions of whether the labrum represents the anterior-most segment, or alternatively of the intercalary segment, and the insect head is 6 segmental or 7 segmental mode are still part of ongoing debate.

Fossil evidence reveals that the order of arthropod head segmentation is conservative and deeply rooted in the first arthropods. None of the structure has ever been observed from fossils at a position anterior to the ocular segment in early arthropods. The 6-segmental mode for insect head and the labrum as fused appendages of the intercalary segment are well grounded also by fossil observation.

\section{Evolution in Panarthropod appendages}

The diverse arthropod fauna together with their worm-like ancestors provide a unique window for establishing the evolutionary scenario of the arthropod appendages. It suggests that the arthropods are derived from a worm-like ancestor in close resemblance to the "Hallucigenia+Cardiodyctyor" clade. This presumed worm-like ancestor had a simple elongated body divided into serial segments. Each segment had a pair of uniramous appendages that were soft-bodied and unjointed in a single tabular form. These appendages consisted of multiple annulations, and lacked intrinsic musculature. The preservation of a central cavity in some appendages suggests that these limbs were hydraulic. The appendages were paired and undifferentiated except for head appendages that are in a more dorsal location and slender.

The evolutionary origin of the Arthropoda is marked by the transformation of the head appendages into sensorial organs, and in the transformation of the uniramous trunk appendages into biramous appendages (Fig. 11, A-B). The post-antennal limbs in the first arthropods were tubular, slowly tapered and multi- 
annulated, bearing a striking resemblance with those in worm-like ancestors. They were composed of 17-20 articles, which are regularly ring-shaped, and connected to each other by a pivot joint (Hou etal., 1999;2004). The presence of a pivot joint suggests the presence of intrinsic muscles and that these ring-shaped articles were true segments.

The PD (proximodistal) specification lays the core in the evolutionary change of the limb design. This change drove the limb in a progressively increasing in differentiation along main axis by stepwise from the simple, multi-segmented tubular limb (Fig. 12, B-C) to bipartite design (Fig. 12E), via of intermediate step (Fig. 12D). The limb design in intermediate step as exemplified by Saperion and Canadaspis displays a clear P-D domain differentiation, with an expanded multi-segmented proximal domain. The transformation of this intermediate form into limb with two functional domains is likely marked with fusion of multisegmented proximal domain into a single-segmental proximal domain known as basipod.

Both limb and antennae in extant arthropods share the same PD-axis patterning genes including: Distal-less (DI), dachshund (dac) and homothorax ( $h$ th) during their development (Dong etal., 2001). These patterning genes are either co-existent each other, or in a mutually exclusive interaction. Among the two different states of interation in these patterning genes, the mutually exclusive regulatory one has competence for developing sharp boundary between domains. Both the limb and antennae as exemplified by proarthropods are in a simple tubular shape with least PD differentiation in early arthropods. This mutually exclusive regulatory interaction for limb or antennae patterning had not yet appeared in the early arthropods. Presence of bipartite atnenae known as "prochelicerae" in stem groups of Chelicerata and bipartite limb among the stem groups of Euarthropoda implies that this mutually exclusive regulatory interaction of the patterning genes had evolved for helping reaction of the sharp boundary between the domains both in antennae and in limbs.

The appendage differentiation between head and trunk implies that the two axial molecular domains, e.g. Otd/ems and Hox genes had been established at the very beginning of arthropod evolutionary history. The Otd/ems genes in the head region were selectively expressed for being responsible in the modification of the head simple tubular appendages into stalked compound eyes and antennae respectively. Hox genes were selectively expressed in the trunk region, responsible for biramous appendage development. The exopod is a novel structure in the arthropods and its flap-like form represents an extended pouch of the body wall, which resembles with insect wing in general morphology and presumably had a gene cassette similar to that in wing developing of the extant insects.

Euarthropoda has been defined as monophyletic both on a 5segmental head and the post-antennal limb design (Walossek, 1999; Maas and Walossek, 2001). The authors proposed that the post-antennal limb in Euarthropoda has a rigid, anterior-posterior compressed proximal limb portion (the basipod) and a 7-segmented endopod (Fig. 4, I). This bipartite limb design along its main axis however does not always appear among the stem groups of the Euarthropoda. The post-antennal limbs in numerous species among the distally related stem-groups of the Euarthropoda (Canadapsis, Isoxus, Ercaia, Primicaris, Tanglangia, Fortiforceps, Leachoilia, Saperion and bradoriids) do not appear in an expected bipartite design but in a simple, sub-tubular shape with slight differentiation along their main axis (Fig. 4, E-H). These limbs consist of 9 to 15 segments. It implies that this bipartite limb design is not monophyletic. The A-P compressed basipod with an expanded and serrated inner edge is likely associated with feeding activity for breaking large food items into pieces and for anterior transportation of food into mouth. The origination of the expanded basipod with a serrate inner edge therefore is a pivotal event for changing the feeding behavior from a microphagous into a macrophagous organism.

The speciation of the appendages in arthropods has evolved roughly in order of the anterior toward posterior along body axis during arthropod evolution. The first event of appendage speciation was marked by the transformation of the first appendage into a visual organ, the eye stalk. The following event was the modification of the short limb-like structure in the second segment into a whip-like sensorial organ or grasping organ separately at transitional stage from proarthropods to euarthropods.

The speciation of the post-antennal appendages in the head of the Mandibulata is represented by three separate events. The early event exemplified by Ercaiais marked by the transformation of the first post-oral appendage into the $2^{\text {nd }}$ antennae (Fig. 4, J-K). The newly discovery of Early Cambrian eucrustaceans both from north-eastern Yunnan, China (Zhang et al., 2007) and from Shropshire, England (Sivetter et al. 2001) suggests that the origination of gnathus appendages followed soon after the origination of the $2^{\text {nd }}$ antenna. The gnathal appendages (called mandible, maxilla 1 and maxilla 2) are the feeding organs, representing modified structures of the second to fourth postantennal appendages.

The intercalary segment represents the first post-antennal segment both in insects and myriopods and it has long been interpreting as an appendage-less segment. The molecular studies (Boyan et al. 2002; Popadic et al. 1998) and the presence of tritocerebrum-originated nerves (Boyan et al., 2002) propose that the labrum is the fused paired appendages of the intercalary segment. The modification of the $2^{\text {nd }}$ antennae into a feeding organ, the labrum, is one of the important evolutionary changes leading to the lines of insects and Myriopods.

The differentiation of the appendages also occurred in order from the caudal one to the anterior. The loss of appendages characterizes this anterior-directed differentiation, linked to the process of abdominalization (Boxshall, 2004). Abdominalization may have occurred repeatedly in the evolutionary history of the arthropods. Fuxianhuia is the fossil representive of the earliest abdominalization event at the very beginning of arthropod evolutionary history.

\section{Molecular and morphological head/trunk boundary evolu- tion in Panarthropoda}

Molecular and genetic research has confirmed that all bilaterial animals, including arthropods and humans, possess a common genetic mechanism of the Hox cluster genes for patterning the anterior/posterior $(A / P)$ axis along the body main axis except for its anterior-most part, which is in outside of Hox gene expression domain. Recently it has become evident that the anterior margin of the Hox gene domain is conserved among different extant arthropod groups, which lie at the position closely related to the border between the anterior and 
posterior developing head of the extant arthropods but not tied to the morphological boundary between head and trunk (Fig. 11). The anterior head outside of the Hox gene expression is comprised of the two segments, e.g. the anterior ocular and posterior antennal segment, which is innervated by protocerebrum and deutocerebrum respectively. The otd Otx genes are involved both in the anterior head and the rostral brain patterning. The boundary of the above two developing body subdivisions, e.g. the anterior otd/Otxand posterior Hoxspecified region are conserved not only across the different extant arthropod groups but throughout the different bilaterian animals also. That is why the fact that the molecular boundary does not match with the morphological head/trunk boundary remains difficult to understand. The fossils may provide the answer.

The morphological boundary of the head/trunk is not conservative. The trunk in proarthropods represents the post-antennal part of the body and the boundary between the head and trunk matches well with the molecular boundary between the Hox gene expression region anteriorly and the ems/otd gene expression region posteriorly. The arthropod head has a tendency of expansion with posterior displacement of the morphological head/trunk boundary and that is why the molecular boundary has a more anterior position than the morphological boundary (Fig. 11).

The head-segment-gain expansion characterizes the arthropod head evolution and it is achieved through the posterior shifting of the head rear border. The original position of the head/trunk boundary in arthropods as exemplified by proarthropods was situated at the rear margin of the antennal segment at a much more anterior position than that in extant arthropods. It implies that the molecular boundary of the anterior otd Otxand the posterior Hox domain is very conserved and ancient, and its relationship with head segmentation has not changed since its first establishment in the earliest arthropods.

This ancient head/trunk boundary has morphologically vanished, however, leaving virtually no distinct morphological mark in all the extant arthropods except for few extant species. For instance, in developing Drosophila, a transient structure known as the cephalic furrow (CF) may represent the relic of this ancient head/trunk boundary. The CF lies at the juxtaposition of the patterning system that defines the procephalic and segmental germ (Costa et al., 1993; Vincent et al., 1997) and the cells in thisntransient structure all unfold back onto the surface of the embryo contributing to the ectoderm in later stages (Costa et al., 1993), and is interpreted as an early organizer region analogous to the midbrain-hindbrain border in vertebrates (Bally-Cuif \& Wassef, 1995; Joyner, 1996). The antennal segment forms a posterior part of the early arthropod head and it bears a very large and posteriorly-extended cephalic shield. This large and posterior-extended tergite of the antennal segment is a character of the first arthropod head and a similar structure also reappears in some extant Crustacea (Casanova et al., 2002).

\section{Is the tripartite brain deeply rooted?}

The developmental regulatory genes of the orthodenticle (otd Otx) gene family and the Hox gene family not only act in the specification of the embryonic, anterio-posterior body axis but also are involved in the brain development of both insects and mammalians. The otdl Otx genes are involved in their rostral part of the brain development and the Hoxgenes in their caudal brain development. The molecular and genetic similarity between insects and mammalians in their brain development has led some to draw the conclusion that a tripartite organization of the embryonic brain was already established in the last common urbilaterian ancestor of protostomes and deuterostomes (Hirth et al., 2003).

The present study however denies this early origin of the tripartite brain organization. The arthropods have readable head segments and their head segments and related appendages are closely related to brain regionalization. The relationship of the head segment (related structure) with brain regionalization is consistent across distally-related groups of the extant arthropods. It implies that this relationship is very conserved and ancient, and has been established since the first appearance of the arthropods. The visual system in the ocular segment is an important component of the protocerebrum and the olfactory centers of antennal segment is the major component of the deutocerebrum. As exemplified by Lower Cambrian proarthropods, all these systems and the related protocerebrum and deutocerebrum already presented in the first arthropods.

The caudal brain comprises the posterior subesophageal ganglion and three subesophageal neuromeres, which are connected to the second antennal and three gnathal segments of the posterior head, respectively. It is connected with the postantennal head segments and apparently had not yet developed in the first arthropods, whose post-antennal head had not yet developed. The caudal brain is therefore a secondarily derived structure and likely originated from modification of the trunk ganglions. In extant insects, the caudal brain (tritocerebrum) is composed of the mandibular, maxillary and labial neuromeres connected with respectively with feeding organs including: labrum, mandibular, maxillary, and labial. The stem groups of Euarthropoda have only three post-oral segments and related unspecialized appendages. These post-oral head segments and related appendages are in a striking homology with those in the trunk. The caudal brain had unlikely evolved in early euarthropods.

\section{Origin of the neural crest cells}

The crest animals contain both craniates and the extinct stemlineage craniates. Among the Early Cambrian crest animals, Haikouella and Yunnanozoon were the most-primitive. These animals are preserved with products of neural crest cells (cartilagous branchial bars with gill rays, pharyngeal denticles) and show evidence of the presence of branchiomeric ventilatory muscles. These muscles are produced essentially through neural crest cell signaling (Graham and Smith, 2001), suggesting the presence of such neural crest cells. Haikouellaand Yunnanozoon were definite crest animals. In addition to the emergence of the neural creast cells, the animals also display some other craniate features including a large differentiated brain, protovertebrae, nostrils and a pair of lateral eyes, lower and upper lips. But they lacked some craniate features, such as a skull, ears, telencephalon, and fin rays. It seems obvious that the craniate traits had evolved through two separate evolutionary events. The emergency of the neural crest cells, and development of relatively large 
brain, lateral eyes, nostrils, upper and lower lips, protovertebrae, pharyngeal denticles, and widely-spaced and jointed thick branchial arches characterize the first event, which are represented by the extinct stem group of the crest animals including Haikouella and Yunnanozoon. Haikoichthus and Myllokunmingia also were pre-craniate crest animals, but more advanced than Haikouella and Yunnanozoon. The following evolutionary event is characteristic of the development of other craniate characters including a skull, ears, telencephalon, and fin rays, and gave rise to craniates.

Neural crest cells derived from almost the entire length of the anterior-posterior axis of the side edges of the crest of the neural plates, except for anterior to the prospective diencephalon corresponding to telencephalon, where the neural crest cells are not formed. The cephalic neural crest cells derived from neural folds caudal to the epiphylis (corresponding to the region of the posterior diencephalon, mesencephalon and rhombencephalon) exerts a critical effect of the rostral protrusion of the eyes first and then the cerebral hemispheres beyond the anterior end of notochord (Etchevers et al., 1999; Creuzet et al., 2006). The anterior border of the neural crest presumably first established at the first emergency of the crest animals and it was situating at anterior margin of the head (corresponding to anterior margin of the diencephalon) in the first crest animals. The relationship of the anterior border of the neural crest with brain seems to be conserved and has no change since its first establishment. The telencephalon that lies anterior to the diencephalon is a novel structure and had originated in the precraniate/crabniate transition through the anterior expansion of the brain. It is why the neural cress cells are not formed in the anterior-most portion corresponding to the telencephalon.

The dorsal midline ectoderm in invertebrate chordates, including extant tunicates and amphioxus, expresses many genes (BMP2, Pax3/7, Msk, DIl, and Snaih) identical to those in vertebrate neural crest cells (Holland and Holland, 2001; Wada, 2001). Many of the cis-regulatory elements for the positioning of the neural crest cells are also present in amphioxus (Manzanares et al., 2000). The remarkable similarity of the expression patterns between the vertebrate neural crest cell and ascidian dorsal midline epidermis had led Wada (Wada, 2001) denying neural crest cells as a novel vertebrate cell. Intriguingly, the cells expressing these genes in tunicate and amphioxus do not migrate; none of them differentiate into a wide range of tissues (Holland and Holland, 2001). Why do these ectodermal cells in amphioxus not evolve into neural crest cells, and what are they waiting for?

It is now known that the two transcription factors AP2 and Distal-less are critical in the formation of neural crest cells. The Distal-less gene in amphioxus has only one copy per haploid genome while in vertebrates it has 5 or 6 closely related copies originating from a single ancestral gene resembling that in amphioxus (Neidert etal., 2001). These distal-less homologues have established new functions and at least 3 of them function in the patterning of neural crest cells. All these suggest that the acquisition of the migratory and differentiation properties of the ectodermal cells in amphioxus is likely waiting for the duplication and divergence of the Distal-less genes (Holland et al., 1996) and for the archivement of novel regulatory mechanism of Hox genes (Wada, 2001).

Amphioxus has only a single Hoxgene cluster with 13 genes, which are arranged in the same order as the corresponding mouse genes. Within the craniates, the Lampreys Petromyzon marinus and Lampetra fluviatilis may have between 2 and 4 Hox gene clusters and the rest of the craniates, including the "lower" craniate the Hagfish Eptatretus stoutii, have 4 or more Hoxgene clusters. This difference suggests that craniates have evolved at least two runs of wholesale duplication of the genome. The origination of the neural crest cells in the first crest animals including Haikouellaand Yunnanozoonsuggests that the first run of genome duplication had occurred at the beginning of the evolutionary history of the crest animals in the Early Cambrian.

\section{Cristozoa groundplan in number of the branchial system}

Pharyngeal arches (or pouches) are a basic chordate feature. They are numerous (up to a few hundred) and closely spaced in adults both in invertebrate chordates (ascidians and cephalochordates) and in hemichordates. In contrast to invertebrate chordates and hemichordates, the crest animals have much fewer and widely spaced branchial arches (or pouches), mostly no more than seven, except for agnaths, which have more branchial arches (or pouches) both in the living hagfish Eptatretus and in fossil agnathans (Janvir, 2004). The number of the gillcompartments in Siluian-Devonian galeaspids displays up to 45 ((Janvir, 2004).

The brachial arches in the groundplan of the crest animals, as exemplified by Yunnanozoonand Haikouella, is characterized by having only 6 post-madibular branchial arches, and a mandibular arch, which developed during the evolutionary stage of the precraniate crest-animals but had not yet evolved at the very beginning of the pre-craniate crest animals such as Haikouella. The branchial arches in the pre-craniate crest animals were morphologically slightly differentiated along their D-V axis and among different branchial arches.

The development of the branchial arches among the invertebrate chordates, especially in amphioxus, yields intriguing insight into the evolutionary origin of the branchial system in the crest animals. The branchial slits in extant amphioxus larvae number only a few and they first developed in the mid-ventral line and moved to the right side after 14 gill slits had formed(Young, 1981). A set of additional 8 gill slits are added to the first row after this. The larvae become bilaterally symmetrical by removing a set of 8 gill slits from the first 14 right row slits to the left and the loss of the remaining 6 gill slits. Further slits in amphioxus are added in pairs during development. The development of 8 pairs of slits in larvae is critical and especially interesting for understanding the origin of cristozoan branchial arches because the number of slits is similar to that in the groundplan of the crest animals. The branchial system with just a few branchial arches in Cristozoa is likely a larval version of the pre-Cristozoa ancestor achieved through paedomorphic processes.

The anterior-most branchial arch is the mandibular one, which appeared among the pre-craniate crest animals. The groundplan of the cristozoan mandibular arch, as exemplified by Yunnanozoon, is with a slight differentiation along its dorso-ventral (D-V) axis. Extant lamprey also have no obvious D-V differentiation. The transformation of the mandibular brachial arch into the jaw is marked by $\mathrm{D}-\mathrm{V}$ speciation of the mandibular branchial arch, representing one of the earliest evolutionary novelties in the gnathostome vertebrate history. The establishment of the Hox gene-coded anterior-posterior (AP) axis and the $D / x$-gene coded 
dorsal-ventral (DV) axis in the pharyngeal area presumably are responsible for this event (Shigetani et al., 2005). No obvious D$\mathrm{V}$ axial speciation of the mandibular arch and the slight differentiation between the branchial arches imply that this Cartesian grid-like specification developmental mechanism had not yet been established in both the pre-craniate crest animals and in the agnathus.

\section{Acknowledgments}

I thank Drs S. Dornbos (Univ. of Wisconsin-Milwaukee, Milwaukee, WI) for view both of an earlier and submitted version of the manuscript and M. Zhu (Inst. of Vertebrate Palaeontology and Palaeoanthropology, Chinese Academy of Sciences, Beijing) for his helpful comments on the submitted manuscript. This research was supported by Chinese Academy of Science Grant KZCX3-SW-14; National Basic Research Program of China (Grant 2007CB815800; 2006CB 806400); National Science Foundation of China (Grant 40432006; 40772001); and 111Project and 985-2 Project of Nanjing University.

\section{References}

ALDRIDGE, R.J., HOU XIAN-GUANG, SIVETER, D.J. \& GABBOTT, S.H., 2007. The systematics and phylogentic relationships of vetulicolians. Palaeontology 50: 131-168.

BALL-CUIF, L., WASSEF, M.(1995). Determination events in the nervous system of the vertebrate embryo. Curr. Op. Genet. Dev. 5: 450-458

BERGSTRÖM, J., HOU XIAN-GUANG, (1998). Chengjiang arthropods and their bearing on early arthropod evolution. In Arthropod Fossils and phylogeny. (Ed. Edgecombe, G.D.). pp. 151-184. Columbia University Press, New York.

BOXSHELL, G.A. (2004). The evolution of arthropod limbs. Biol. Rev. 79: 253-300.

BERGSTRÖM, J. AND HOU XIAN-GUANG (2003).Cambrian arthropods: a lesson in convergent evolution. 89-96. In The new panorama of animalevolution. (Eds. Legakis, A., Sfenthourakis, S., Polymeni, R. \& Thessalou-Legaki, M.). Proceedings, XVIII International Congress of Zoology. Pensoft, Sofia-Moscow, xvi+738pp.

BOYAN, G.S., WILLIAMS, J.L.D., POSSER, S., BRÄUNIG, P. (2002). Morphological and molecular data argue for the labrum being non-apical, articulated, and the appendage of the intercalary segment in the locust. Arthrop. Struct. Dev. 31:65-76.

BRIGGS, D.E.G. (1992). Phylogenetic significance of the Burgess Shale crustacean Canadaspis. Acta Zoological (Stockholm) 73: 293-300.

BRIGGS, D.E.G. (1994). Giant predators from the Cambrian of China. Science264, 1283-1284

BRIGGS, D. E. G., LIEBERMAN, B. S., HALGEDAHL, S. L. AND JARRARD, R. D. (2005). A new metazoan from the Middle Cambrian of Utah amd the nature of the Vetulicolia. Palaeontology 48: 681-686.

BRUSCA, R.C., BRUSCA, G.J. (1990). Invertebrates. Sinauer Associates, Sunderland, Massachusetts.

BUTT, F.H. (1960). Head development in the arthropods. Biological Reviews of the Cambridge Philosophical Society 35: 43-91.

CARON, J. B. (2006). Banffia constricta, a putative vetulicolid from the Middle Cambrian Burgess Shale. Transactions of the Royal society of Edinburgh: Earth Sciences 96 (for 2005), 95-111.

CASANOVA, B., JONG, L., MOREAU, X. (2002). Carapace and mandibles ontogeny in the Dendrobranchiata (Decapoda), Euphausiacea, and Mysidacea (Crustacea): a phylogenetic interest. Can. J. Zool. 80: 296-306.

CHEN AI-LIN, FENG HONG-ZHEN, ZHU MAO-YAN, MA DONG-SHENG AND LI MING (2003). A new vetulicolian from the Early Cambrian Chengjiang Fauna in Yunnan of China. Acta Geologica Sinica 77: 281-287.

CHEN JUN-YUAN (2004). The Dawn of Animal World. Jiangsu Publishing House of Science and Technology, Nanjing.

CHEN J.-Y. (2008). Early Crest Animals and the insight they provide into the origin of craniates. Genesis 6: 623-639.

CHEN JUN-YUAN, BOTTJER, D.J., DAVIDSON, E.H., DORNBOS, S.Q., GAO XIANG, YANG YONG-HUA, LI CHIA-WEI, LI GANG, WANG XIU-QIANG, XIAN DING-CHANG, WU HUNG-JEN, HWU YEU-KUANG, TAFFOREAU, P. (2006).
Phosphatized Polar Lobe-Forming Embryos from the Precambrian of Southwest China. Science 312: 1644-1646.

CHEN JUN-YUAN, BOTTJER, D.J., OLIVERI, P., DORNBOS, S.Q., GAO FENG, RUFFINS, S., CHI HUI-MEI, LI CHIA-WEI, DAVIDSON, E.H. (2004a). Small Bilaterian Fossils from 40 to 55 Million Years Before the Cambrian. Science 305 218-222.

CHEN JUN-YUAN, WALOSZEK, D., MAAS. A. (2004b). A new 'great-appendage' arthropod from the Lower Cambrian of China and homology of chelicerate chelicerae and raptorial antero-ventral appendages. Lethaia 37: 3-20.

CHEN JUN-YUAN, BRAUN A., WALOSZEK D., PENG QING-QING, MAAS. A. (2004c). Lower Cambrian yolk-pyramiod embryos from southern Shaanxi, China. Prog. Nat. Sci. 14: 167-172.

CHEN JUN-YUAN, DIETER WALOSZEK, D., MAAS, A., BRAUN, A., HUANG DIYING, WANG XIU-QIANG, MARTIN STEIN, M. (2007a). Early Cambrian Yangtze Plate Maotianshan-shale macrofauna biodiversity and the evolution of predation. Palaios 254: 250-272.

CHEN JUN-YUAN, SCHOPF, J.W.`BOTTJER, D. J., ZHANG CHENG-YU, KUDRYAVTSEV ANATOLIY B., TRIPATHI ABHISHEK B., WANG XIU-QIANG, YANG, YONG-HUA, GAO XIANG, YANG YING (2007b). Raman Spectra of a Lower Cambrian ctenophore embryo from SW Shaanxi, China. Proc. Nat/. Acad. Sci. USA 106: 6289-6292.

CHEN JUN-YUAN, DZICK, J., EDGECOMBE, G.D., RAMSKÖLD, L., ZHOU GUIQING, (1995a). The earliest chordate from Early Cambrian, Yunnan, China Nature 377: 720-722.

CHEN JUN-YUAN, EDGECOMBE, G.D., RAMSKÖLD, L., ZHOU GUI-QING (1995b). Head Segmentation in Early Cambrian Fuxianhuia: Implications for Arthropod evolution. Science 268: 1339-1343.

CHEN JUN-YUAN, ZHU MAO-YAN, ZHOU GUI-QING (1995c). The early Cambrian medusiform metazoan Eldonia from Chengjiang Lagerstätte. Acta Palaeontologica Polonica 40: 213-244.

CHEN JUN-YUAN, ZHOU GUI-QING, RAMSKÖLD, L. (1995d). A new Early Cambrian onychophoran-like animal Paucipodia gen. nov., from the Chengjiang fauna, China. Transaction of the Royal Society of Erdinburgh, Earth Sciences 85: $275-282$

CHEN JUN-YUAN, EDGECOMBE, G.D., RAMSKÖLD, L. (1997). Morphological and ecological disparity in Naraoiids (arthropoda) from the Early Cambrian Chengjiang fauna, China. Records of the Australia Museum 47: 1-24.

CHEN JUN-YUAN, HOU XIAN-GUANG, LU HAO-ZHI (1989). Early Cambtian netted scale-bearing worm-like sea animal. Acta Palaeontologica Sinica, 28, 1 26. [In Chinese, with English summary].

CHEN JUN-YUAN, ERDTMANN, B.D. (1991). Lower Cambrian fossil Lagerstätte from Chengjiang, Yunnan, China: Insights for reconstracting early metazoan life. In The early evolution of Metazoa and the significance of problematic taxa. (Eds. Simmoneta and Conway Morris).Cambrige, Cambridge Press: 57-75.

CHEN JUN-YUAN and HUANG DI-YING (2002a). A possible Lower Cambrian Chaetognath (Arrow Worm). Science 298: 197.

CHEN JUN-YUAN, HUANG DI-YING, LI CHIA-WEI (1999). An Early Cambrian craniate-like chordate. Nature 402, 518-522.

CHEN JUN-YUAN, HUANG DI-YING, PENG QING-QING, CHI HUI-MEI, WANG XIU-QIANG, FENG MAN (2003). The first tunicate from Early Cambrian of south China. Proc. Natl. Acad. Sci. USA 100: 8314-8318.

CHEN JUN-YUAN, LI CHIA-WEI (1997). Early Cambrian Chordate from Chengjiang, China. In The Cambrian Explosion and the fossil record. (Eds. Chen Jun-Yuan, Cheng Yeh-Nian and Van Iten, H.). Taichung: National Museum of Natural History Press: 257-2730

CHEN JUN-YUAN, LI CHIA-WEI (2000). Distant ancestor of mankind unearthed: 520 million year-old fish-like fossils reveal early history of vertebrates. Science Progress 83: 123-133.

CHEN JUN-YUAN, OLIVERI, P., GAO FENG, DORNBOS, S.Q., LI CHIA-WEI, BOTTJER, D.J., DAVIDSON, E.H (2002a). Precambrian Animal Life: Probable Developmental and Adult Cnidarian Forms from Southwest China. Dev. Biol. 248: $182-1960$

CHEN JUN-YUAN, OLIVERT, P., LI CHIA-WEI., ZHOU GUI-QING, GAO FENG, HAGADORN, J.W., PETERSON, K.J., DAVIDSON, E.H. (2000). Precambrian animal diversity: Putative phosphatized embryos from the Doushantuo Formation of China. Proc. Natl. Acad. Sci. USA 97: 4457-4462.

CHEN JUN-YUAN, VANNIER J., HUANG DI-YING (2001). The origin of 
crustanceans: new evidence form the Early Cambrian of China. Proc. Royal Soc, London B268: 1-7.

CHEN JUN-YUAN, ZHOU GUI-QING (1997). Biology of the Chengjiang Fauna. Bulletin of National Museum of Natural Science 10: 11-106.

CHEN LIANG-ZHONG, LUO HUI-LIN, HU SHI-XUE, YIN GI-YUN, JIANG ZHIWEN, WU ZHI-LIANG, LIFENG, CHEN AI-LIN (2002). Early Cambrian Chengjiang Fanna in Eastern Yunnan, China, 199pp, 28 pls. Yunnan Science and Technology Press, Kunming. [ In Chinese, with English summary].

CLARK, H.L. (1912). Fossil holothurian. Science 35: 274-278.

CONWAY MORRIS, S. (1977). Fossil priapulid worms. Special Papers in Palaeontology 20: 1-95.

CONWAY MORRIS, S. (2000). The Cambrian explosion: slow-fuse or megatonnage? Proc. Natl. Acad. Sci. USA 97: 4426-4429.

CONWAY MORRIS, S., COLLINS, D.H. (1996). Middle Cambrian ctenophores from the Stephen Formation, British Columbia. Philos. Trans. Royal Soc. London B 351: 279-308.

CONWAY MORRIS, S., ROBISON, R.A. (1988). More soft-bodied animals and algae from the middle Cambrian of Utah and British Columbia. University of Kansas Paleontological Contribution Paper 122: 1-48.

COSTA, M., SWEETON, D., WIESCHAUS, E. (1993). Gastrulation in Drosophila: Cellular mechanisms of morphogenetic movements, pp 425-465. In The deve/opment of Drosophila melanogaster. (Eds. Bate, M. and Hartenstein, V.). Cold Spring Harbor Laboratories: Long Island NY.

CREUZET, S.E., MARTTINEZ, S., DOUARIN, N.M. (2006). The cephalic neural crest exert a critical effect on forebrain and midbrain development. Proc. Nat/. Acad. Sci. USA 103: 14033-14038.

CRONEIS, C., MCCORMACK (1932). Fossil Holothurioidea. J. Paleontology 6: 111-148.

DORNBOS, S.Q., and CHEN, J.Y. (2008). Community palaeoecology of the Early Cambrian Maotianshan Shale biota: Ecological dominance of priapulid worms. Palaeogeo. Palaeoclimat. Palaeoecol. 258: 200-212.

DONG, P. D., CHU, J. \& PANGANIBAN, G. (2001). Proximodistal domain specification and interactions in developing Drosophila appendages. Development 128: $2365-2372$.

DUNLOP, J.A. (1999). Pasando revista a la evolución de los quelicerados. In Evolución y filogenia de Arthropoda, (Eds. Melic, A., De Haro, J.J., Mendez, M. and Ribera, I.). pp. 255-272. Boletin de la Sociedad Entomologica Aragonesa 26.

DZIK, J., ZHAO YUAN-LONG, ZHU MAO-YAN (1997). Mode of life of the Middle Cambrian eldonioid lophophorate Rotadiscus. Palaeontology 40: 385-396.

EASTHAM, L.E.S. (1930). The embryology of Pieris rapae-organogeny. Philosophical Transactions of the Research Society of London Biological Science 219: 2-50.

ETCHEVERS, H., COULY, G., VINCENT, C., LE DOUARIN, N.M. (1999). Anterior cephalic neural crest is required for forebrain viability. Development 126: 35333543.

FINKELSTEIN, R., PERRIMON, N. (1991). The molecular genetics of head development in Drosophila melanogaster. Development 112: 899-912.

GEE, H. (2001). On being vetulicolian. Nature 414: 407-409.

GERHART, J. \& KIRSCHNER, M. (1997). Cells, Embryos, and Evolution. Blackwell Science Ltd, Malden, MA.

GOULD, S.J. (1989). Wonderful Life: the Burggess Shale and the nature of history, Norton, New York.

GRAHAM, A.\& SMITH, A. (2001). Patterning the pharyngeal arches. BioEssays23: 54-61.

HALL, B.K. (1998). Evolutionary Developmental Biology. Chapmman and Hall, London, New York.

HIRTH, F., KAMMERMEIER, L., FREI, E., WALLDORF, U., NOLL, M., REICHERT, $H$. (2003). An urbilaterian origin of the tripartite brain: developmental genetic insights from Drosophila. Development 130: 2365-2373.

HOLLAND, L.Z.\& HOLLAND, N.D. (2001). Evolution of neural crest and placodes: Amphioxus as a model for the ancestral vertebrate. J. Anat. 199: 85-98.

HOLLAND, N.D., CHEN JUN-YUAN (2001). Origin and early evolution of the vertebrates: new insights from advances in molecular biology, anatomy, and palaeontology. BioEssays 23: 142-151.

HOLLAND, N.D., PANGANIBAN, G., HENYEY, E.L., HOLLAND, L.Z. (1996).
Sequence and developmental expression of AmphiDII, an amphioxus Distalless gene transcribed in the ectoderm, epidermis and nervous system. Develop ment122: 2911-2920

HOU XIAN-GUANG (1987). Three new large arthropods from Lower Cambrian, Chengjiang, eastern Yunnan. Acta Paleontological sinica 26, 272-285. [In Chinese, with English summary].

HOU XIAN-GUANG, ALDRIDGE, R.J., BERGSTRÖM, J., SIVETER, D.J., SIVETER, D.J., FENG XIANG-HONG (2004). The Cambrian Fossils of Chengjiang, China: The Flowering of Early Animal Life. Blackwell Science Ltd, Malden, MA, USA Oxford, UK.

HOU XIAN-GUANG, ALDRIDGE, R.J., SIVETER, DAVID, J., SIVETER, DEREK, J., FENG XIANG-HONG (2002). New evidence on the anatomy and phylogeny of the earliest vertebrates. Proc. Royal Soc. London B 269: 1865-1869.

HOU XIAN-GUANG, BERGSTRÖM, J. (1991). The arthropods of the Lower Cambrian Chengjiang fauna, with relationships and evolutionary significance. In The early Evolution of Metazon and the Significance of Problematic Taxa, (Eds. Simonetta, A.M. and Conway Morris, S.). pp. 179-187. Cambridge University Press, Cambridge.

HOU XIAN-GUANG, BERGSTRÖM, J. (1995). Cambrian lobopodians-ancestors of extant onychophorans? Zoological Journal of the Linnean Society 114: 3-19.

HOU XIAN-GUANG, BERGSTRÖM, J. (1997). Arthropods of the Lower Cambrian Chengjiang fauna, southwest China. Fossils and Strata 45.

HOU XIAN-GUANG, BERGSTRÖM, J., WANG HAI-FENG, FENG XIANG-HONG, CHEN AI-LIN (1999). The Chengjiang fauna. Exceptionally well-preserved animals from 530 millions years ago. 170pp. Yunnan Science and Technology Press, Kunming, Yunnan Province, China. [In Chinese, with English summary].

HOU XIAN-GUANG, CHEN JUN-YUAN (1989). Early Cambrian arthropod-annelid intermediate sea animal, Luolishania gen. nov. from Chengjiang, Yunnan. Acta Palaeontologica Sincia 28, 207-213. [In Chinese, with English summary].

HOU XIAN-GUANG, RAMSKÖLD, L., BERGSTRÖM, J. (1991). Composition and preservation of the Chengjiang fauna-a Lower Cambrian soft-bodies biota. Zoologica Scripta 20: 395-411.

HUANG DI-YING, CHEN JUN-YUAN, VANNIER J., SAIZ SALINAS, J.I. (2004). Early Cambriansipunculan worms from southwest China. Proc. R. Lond. B 271 1671-1676.

HUANG DI-YING, VANNIER, J., CHEN JUN-YUAN (2004a). Anatomy and lifestyles of Early Cambrian priapulid worms exemplified by Corynetis and Anningvermis from the Maotianshan Shale (SW China). Lethaia 37, 21-33.

HUANG DI-YING, VANNIER, J., CHEN JUN-YUAN (2004b). Recent Priapulidae and their Early Cambrian ancestors: comparisons and evolutionary significance. Geobios 37: 217-228.

HUANG DI-YING (2006). The Early Body Plan, Origin and Evolutionary Radiation of Priapulida. In Originations, Radiations and Biodiversity Changes-Evidences from the Chinese Fossil Record. (Eds. Rong Jiayu, Fang Zong-Jie, Zhou Zhong$\mathrm{He}$, Zhan Ren-Bin, Wang Xiang-Dong, Yuan Xun-Lai). Beijing: Science Press. 125-137, 845-846.

JANVIER, P. (1999). Catching the first fish. Nature 402: 21-22.

JANVIER, P. (2004). Early specializations in the branchial apparatus of jawless vertebrates: a consideration of gill number and size. In Recent Advances in the Origin and Early Radiation of Vertebrates. (Eds. G.Arratia, M.V.H. Wilson \& R. Cloutier). Verlag Dr. Friedrich Pfeil, München, German, pp.25-52.

JIN YU-GAN, HOU XIAN-GUANG, WANG HUA-YU (1993). Lower Cambrian pediculate lingulids from Yunnan, China. J. Paleontology 67: 788-798.

JOYNER, A.L. (1996). Engrailed, Wnt and Pax genes regulate midbrain-hindbrain development. Trends Genet 12: 15-20.

LACALLI, T.C., 2002. Vetulicolians are they deuterostomes? chordates? Bioessays 24: 208-211.

LEMCHE, H. (1960). A possible central place for Stenothecoides Resser, 1939 and Cambridium Hoeny, 1957 (Mollusca Monoplacophora) in unvertebrate phylogeny. Reports of the International Geological Congress, XXISession, Norden22: 92-101.

LI CHIA-WEI, CHEN JUN-YUAN, HUAI, T.E. (1998). Precambrian sponges with cellular structure. Science 279: 879-882.

LIU JIAN-NI, SHU DE-GAN, HAN JIAN, ZHANG ZHI-FEI (2004). A rare lobopod with well-preserved eyes from Chengjiang Lagerst? tte and its implications for origin of arthropods. Chinese Science Bulletin 49: 1063-1071.

LUO HUI-LIN, HU SHI-XUE, CHENG LIANG-ZHONG, ZHANG SHI-SHAN, TAO YONG-HE (1999). Early Cambrian Chengjiang fauna from Kunming Region, 
China, 129pp. 32 pls. Yunnan Science and Technology Press, Kunming. [In Chinese, with English summary].

LUO HUI-LIN, HU SHI-XUE, ZHANG SHI-SHAN, TAO YONG-HE (1997). New occurrence of the early Cambrian Chengjiang fauna from Haikou, Kunming, Yunnan province. Acta Geologica sinica 71: 97-104. [In Chinese, with English summary].

MAAS, A., HUANG DI-YING, CHEN JUN-YUAN, WALOSZEK, D., BRAUN, A. (2007). Maotianshan-Shale nemathelminths Morphology, biology, and thephylogeny of Nemathelminthes. Palaios 254: 288-306.

MADSEN, F.J. (1956). Eldonia, a Cambrian siphonophore-formerly interpreted as a holothurian (sic). Videnskabelige Meddelelserfra Dansknaturhistorisk Forening i Kobenhavn 118: 7-14.

MALLATT, J. (1996). Ventilation and the origin of jawed vertebrates: a new mouth. Zool. J. Linnean Soc. 117: 329-404.

MALLATT, J., CHEN JUN-YUAN (2003). Fossil Sister Group of Craniates: Predicted and Found. J. Morphol. 258: 1-31.

MANZANARES, M., WADA H, ITSAKI N, TRAINOR PA, KRUMLAUF R., AND HOLLAND PW. (2000). Conservation and elaboration of Hox gene regulation during evolution of the vertebrate head. Nature 408: 854-857.

MASS, A., WALOSZEK, D. (2001). Cambrian derivatives of the early arthropod stem lineage, pentostomids,, tardigrades and lobophodians-an "Orsten" perspective. Zoologischer Anzeiger 240: 451-459.

MASS, A., WALOSZEK, D., CHEN JUN-YUAN, BRAUN, A., WANG XIU-QIANG, HUANG DI-YING (2004). Phylogeny and life habits of early arthropods-predation in the early Cambrian sea. Prog. Nat. Sci. 14: 158-166.

MINELLI, A. (2001). A three-phase model of arthropod segmentation. Dev. Genes Evol. 211: 509-521.

NEIDERT, A.D., VIRUPANNAVAR, V., HOOKER, G.W., LANGELAND, J.A. (2001). Lamprey DIx genes and early vertebrate evolution. Proc. Natl. Acad. Sci. USA 98: 1665-1670

POPADIC, A., PANGANIBAN, G., RUSCH, D., SHEAR, W.A., KAUFMAN, T.C. (1998). Molecular evidence for the appendicular origin of the labrum and other structures. Development, Genes Evol. 208. 142-150.

RAFF, R.A. (1996). The Shape of Life: Genes, Development, and the Evolution of Animals Form. University of Chicago Press, London.

RAMSKÖLD, L. (1992). Homologies in Cambrian Onychophora. Lethaia25: 443-460.

RAMSKÖLD, L., CHEN JUN-YUAN (1998). Cambrian Lobopodians: Morphology and Phylogeny. In Arthropod Fossils and Phylogeny. (Ed. Edgecombe). pp. 107-150, Columbia Press.

RAMSKÖLD, L., CHEN JUN-YUAN, EDGECOMBE, G.D., ZHOU GUI-QING (1997) Cindarella and the arachnate clade Xandarellida (Arthropoda, Early Cambrian) from China. Transaction of the Royal Society of Edinburgh. Earth Science 88: 19-38.

REMPEL, J.G. (1975). The evolution of the insect head: the endless dispute. Quaest. Entomol. 11: 7-25

RUPPERT, E.E., FOX, R.S., BARNES, R.D. (2004). Invertebrate Zoology (7th Edition). Brooks/Cole-Thomson Learning, Belmont, CA, USA.

SCHMIDT-OTT, U., TECHNAU, G. (1992). Expression of en and $w g$ in the embryonic head and brain of Drosophila indicates a refolded band of seven segment remnants. Development 116: 111-125.

SCHOLTZ, G. (2001). Evolution of developmental patterns in arthropods-the analysis of gene expression and its bearing on morphology and phylogenetics. Zoology 103: 99-111.

SHIGETANI, Y., SUGAHARA, F., KURATANI, S. (2005). A new evolutionary scenario for the vertebrate jaw. BioEssays 27, 331-338.

SHU DE-GAN, CONWAY MORRIS, S., ZHANG XING-LIANG, CHEN LING, LI YONG, HAN JIAN (1999a). A pipiscid-like fossil from the Lower Cambrian of south China. Nature 400: 746-749.

SHU DE-GAN, LUO HUI-LIN, CONWAY MORRIS, S., ZHANG XING-LIANG, HU SHI-XUE, CHEN LING, HAN JIAN, ZHU MIN, LI YONG, CHEN LIANG-ZHONG (1999b). Lower Cambrian vertebrates from south China, Nature 402: 42-46.

SHU DE-GAN, CHEN LING, HAN JIAN, ZHANG XING-LIANG (2001a). An Early Cambrian tunicate from China. Nature 411: 472-473.

SHU DE-GAN, CONWAY MORRIS, S., HAN JIAN, CHEN LING, ZHANG XINGLIANG, ZHANG ZHI-FEI, LIU HU-QIN, LI YONG, LIU JIAN-NI (2001b). Primitive deuterostomes from the Chengjiang Lagerstätte (Lower Cambrian, China).
Nature 414: 419-424.

SHU DE-GAN, CONWAY MORRIS, S., HAN JIAN, ZHANG ZHI-FEI, YASUI, K., JANVIER, P., CHEN LING, ZHANG XING-LIANG, LIU JIAN-NI, LI YONG, LIU HU-QIN, 2003a. Head and backbone of the Early Cambrian vertebrate Haikouichthus. Nature 421: 526-529.

SHU DE-GAN, CONWAY MORRIS, S., ZHANG ZHI-FEI, LIU JIAN-NI, HAN JIAN, CHEN LING, ZHANG XING-LIANG, YASUI, K., LI YONG (2003b). A new species of Yunnanozoon with implications for deuterostome evolution. Science 299: $1380-1384$.

SHU DE-GAN, ZHANG XING-LIANG, CHEN LING (1996). Reinterpretation of Yunnanozoon as the earliest known hemichordate. Nature 380: 428-430.

SIVETER, D.J., WILLIAMS, M., WALOSZEK, D. (2001). A Phosphatocopid Crustacean with Appendages from the Lower Cambrian. Science 293: 479-481.

SNODGRASS, R.E. (1935). Principles of Insect Morphology. New York, McGraw-Hill.

STEINER, M., ZHU MAO-YAN, LI GUO-XIANG, QIAN YI, ERDTMANN, B.D. (2004). New Early Cambrian bilaterian embryos and larvae from China. Geo/ogy 32: 833-836.

SUN WEI-GUO, HOU XIAN-GUANG (1987). Early Cambrian medusae from Chengjiang, Yunnan, China. Acta Palaeontologica Sinica 26, 257-271. [In Chinese, with English summary].

SUTTON, M.D., BRIGGS, D.E.G., SIVETER, D.J., SIVETER, D.J., ORR, P.J. (2002). The arthropod Offaculus kingi (Chelicerata) from the Silurian of Herefordshire, England: computer based morphological reconstructions and phylogenetic affinities. Proc. R. Soc. London B269: 1195-1203.

VINCENT, A., BLANKENSHIP, J.T., WIESCHAUS, E. (1997). Integration of the head and trunk segmentation systems controls cephalic furrow formation in Drosophila. Development 124: 3747-3754.

WADA, H. (2001). Origin and evolution of the neural crest: A hypothetical reconstruction of its evolutionary history. Dev. Growth Differ. 43: 509-520.

WALCOTT, C.D. (1911). Cambrian geology and paleontology 11, no.3- Middle Cambrian holothurian and medusae. Smithsonian Miscellaneous Collections 57: 41-68.

WALOSSEK, D. (1993). The upper Cambrian Rehbachiella and the phylogeny of Branchiopoda and Crustacea. Fossils and Strata 32: 1-202.

WALOSSEK, D. (1999). On the Cambrian diversity of Crustacea. In Crustaceans and the Biodiversity Crisis (Eds. Schram, F.R. and Von Vaupel Klein, J.C.). 327. Proceedings of the Fouth International Crustacean Congress, Amsterdam, The Netherlands, July 20-24, 1998, 1. Brill Academic Publishers, Leiden.

WALOSSEK, D., MÜLLER, K.J. (1990). Upper Cambrian stem-lineage crustaceans and their bearing upon the monophyletic origin of Crustacea and the position of Agnostus. Lethaia 23: 409-427.

WALOSZEK, D., CHEN JUN-YUAN, MAAS, A. AND WANG XIU-QIANG. (2005) Early Cambrian Arthropods - New Insights into Arthropod Head and Structural Evolution. Arthropod Systematic and Development 34: 189-2050

WALOSZEK, D., MAAS, A., CHEN JUN-YUAN, STEIN, M. (2007). Evolution of cephalic feeding structures and the phylogeny of Arthropoda. Palaios 254: 273-287.

WANG XIU-QIANG, CHEN JUN-YUAN. (2004) Possible developmental mechanisms underlying the origin of the crown lineages of arthropods. Chinese Science Bulletin, 49: 49-53.

XIAO SHU-HAI, YUAN XUN-LAI, KNOLL, A.H. (2000). Eumetazoan fossils in terminsl Proterozic phosphorites. South China. Lethaia 32: 219-240.

XIAO SHU-HAI, YUAN XUN-LAI, STEINER, M., KNOLL, A.H. (2002). Macroscopic carbonaceous compressions in a terminal Proterzoic shale: a systematic reassessment of the Miaohe biota, South China. J. Paleontol. 76: 347-376.

YOUNG (1981). The Life of Vertebrates (3rd edition).Clarendon Press, Oxford.

ZACHARIAS, D., WILLIAMS, J.L.D., MEIER, T., REICHERT, H. (1993). Neurogenesis in the insect brain: Cellular identification and molecular characterization of brain neuroblasts in the grasshopper embrgo. Development 118 : 941-955.

ZHANG XI-GUANG, SIVETERD., WALOSZEK D. AND MAAS A. (2007). An epipoditebearing crown-group crustacean from Lower Cambrian. Nature 448: 595-598.

ZHAO YUAN-LONG, ZHU MAO-YAN (1994). Medusiform fossils of Kaili fanna from Taijiang, Guizhou. Acta Palaeontologica Sinica 33, 272-280. [In Chinese, with English summary].

ZHU MAO-YAN, ZHAO YUAN-LONG, CHEN JUN-YUAN (2002). Revision of the Cambrian medusiform animals Stellostomites eumorphus Sun et Hou and Pararotadiscus guizhouensis (Zhao et Zhu) from South China. Geobios 35: 165185. 


\section{Further Related Reading, published previously in the Int. J. Dev. Biol.}

See our Special Issue Evolution \& Development, edited by Jaume Baguñà and Jordi García-Fernández at:

http://www.ijdb.ehu.es/web/contents.php?vol=47\&issue=7-8

See our Special Issue Fertilization, in honor of David L. Garbers and edited by Paul M. Wassarman and Victor D. Vacquier at:

http://www.ijdb.ehu.es/web/contents.php?vol=52\&issue=5-6

Dynamical patterning modules: a "pattern language" for development and evolution of multicellular form

Stuart A. Newman and Ramray Bhat

Int. J. Dev. Biol. in press doi: 10.1387/ijdb.072481sn

Segmentation, metamerism and the Cambrian explosion Juan Pablo Couso

Int. J. Dev. Biol. in press doi: 10.1387/ijdb.072425jc

On the origin of pattern and form in early Metazoans

Frederick W. Cummings

Int. J. Dev. Biol. (2006) 50: 193-208 [Abstract] [FullText Open Access]

Adaptive walks in a gene network model of morphogenesis: insights into the Cambrian explosion.

Ricard V Solé, Pau Fernández and Stuart A Kauffman

Int. J. Dev. Biol. (2003) 47: 685-693

Morphological and developmental macroevolution: a paleontological perspective. James W Valentine and David Jablonski Int. J. Dev. Biol. (2003) 47: 517-522

The Cambrian "explosion" of metazoans and molecular biology: would Darwin be satisfied?

Simon Conway-Morris

Int. J. Dev. Biol. (2003) 47: 505-515

\section{Preface}

Jaume Baguñà and Jordi García-Fernández

Int. J. Dev. Biol. (2003) 47: 465-467

The first bilaterian organisms: simple or complex? New molecular evidence J Baguna, I Ruiz-Trillo, J Paps, M Loukota, C Ribera, U Jondelius, M Riutort Int. J. Dev. Biol. (2001) 45: S133-S134

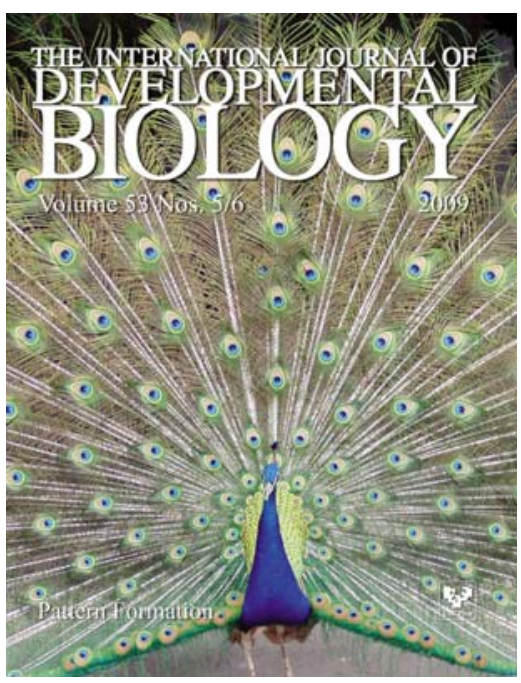

5 yr ISI Impact Factor $(2008)=3.271$
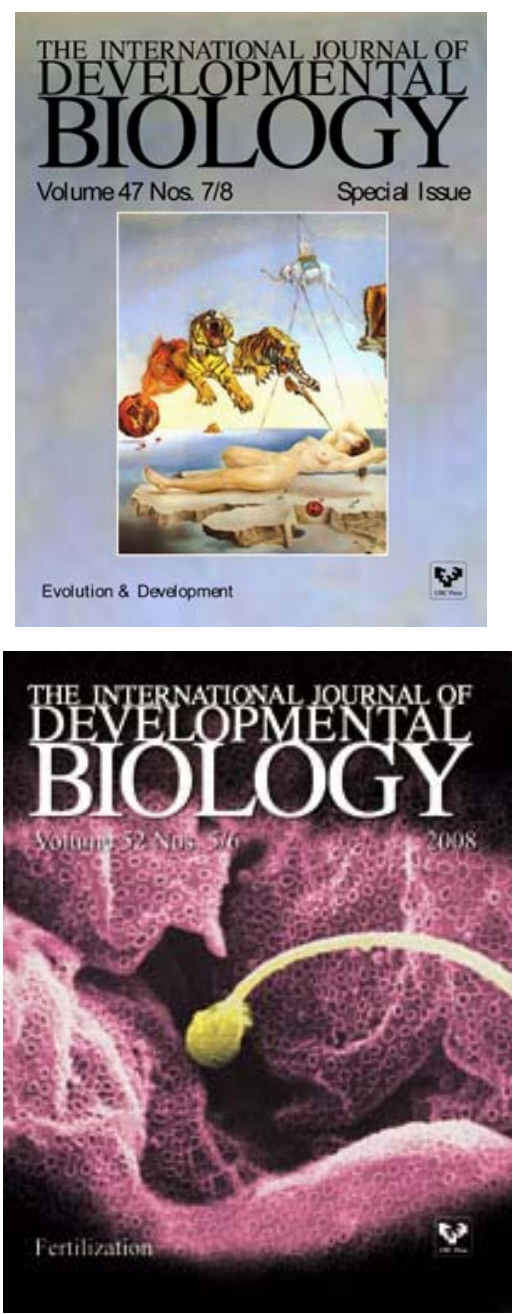